Northwestern University School of Law Northwestern University School of Law Scholarly Commons

Faculty Working Papers

2008

\title{
IF MAJOR WARS AFFECT (JUDICIAL) FISCAL POLICY, HOW \& WHY?
}

Nancy Staudt

Northwestern University School of Law, n-staudt@law.northwestern.edu

\section{Repository Citation}

Staudt, Nancy, "IF MAJOR WARS AFFECT (JUDICIAL) FISCAL POLICY, HOW \& WHY?" (2008). Faculty Working Papers. Paper 153.

http://scholarlycommons.law.northwestern.edu/facultyworkingpapers/153

This Working Paper is brought to you for free and open access by Northwestern University School of Law Scholarly Commons. It has been accepted for inclusion in Faculty Working Papers by an authorized administrator of Northwestern University School of Law Scholarly Commons. 
If Major Wars Affect (Judicial) Fiscal Policy, How \& Why?

by

Nancy Staudt

\begin{abstract}
$\underline{\text { Abstract }}$
This paper seeks to identify and explain the effects of major wars on U.S. Supreme Court decision-making in the context of taxation. At first cut, one might ask why we should even expect to observe a correlation between military activities and judicial fiscal policy. After all, the justices have no authority whatsoever to adopt funding laws intended to relieve the budgetary pressures that tend to emerge in times international crisis. The Court, however, is able to contribute to the wartime revenueraising efforts indirectly by adopting a pro-government stance in the cases it decides in wartime periods. As the probability of a government win increases, the expected revenue to the federal fisc also increases.

Relying on Supreme Court tax decisions issued between the years 1909 and 2000, this paper identifies a strong and positive correlation between major wartime activity and the probability that the government will prevail. This pro-government bias appears to operate through the judicial belief that Congress and the President are better suited to address national emergencies. This perceived imbalance of expertise, however, does not lead the Court to adopt a strategy of total deference, but rather a restricted form that involves accommodation only on issues that Congress and the President have signaled are important to the on-going war activities. These findings are robust and rule out the possibility that the Court is motivated by short-term irrational exuberance for federal policymakers associated with the so-called "rally-effect" that emerges when Americans feel threatened by forces abroad.
\end{abstract}


If Major Wars Affect (Judicial) Fiscal Policy, How \& Why?

by

Nancy Staudt

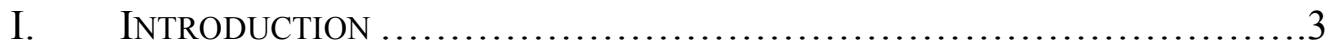

II. TRENDS IN JUdiCIAL FISCAL DECISION-MAKING..................... 8

III. Judicial Incentive Structures in Wartime And Peacetime......... 15

A. Incentive Structures in Constitutional and Statutory Cases:

Distinctions That Matter........................................16

B. $\quad$ Unpacking Judicial Incentives (and Disincentives) to Defer....18

IV. The EFFECT OF WAR On Judicial Fiscal Decision-MAKING?...............23

A. Models and Predictions.......................................24

B. $\quad$ Assumptions and Possible Selection Biases......................227

C. Empirical Results.............................................. 30

V. COnClusion .................................................... 36

Data Coding ApPEndix................................................. 37 
Draft March 21, 2008

Preliminary Draft--Please Do Not Cite or Quote

If Major Wars AfFect (Judicial) Fiscal Policy, How \& Why?

by

Nancy Staudt

\section{INTRODUCTION}

Wars, by any measure, are costly endeavors. Some of these costs are incommensurable and difficult to estimate fully, such as those linked to casualties, human suffering, and death. But many others, including direct expenditures on equipment, training, and deployment, can be calculated with some precision. Current data, for example, indicate that the U.S. government has engaged in seven major wars ${ }^{1}$ over the course of the $20^{\text {th }}$ and $21^{\text {st }}$ centuries at a cost of nearly $\$ 5$ trillion dollars. ${ }^{2}$ As depicted in Figure 1 below, the greatest wartime spike in military expenditures occurred in WWII when government outlays equaled nearly $40 \%$ of GDP. WWI and the Korean war were costly but less so than WWII, and the post-1960 wars, the Vietnam, Gulf, Afghanistan, and Iraq wars, imposed almost no perceptible change in the military spending trends. ${ }^{3}$

\footnotetext{
* Class of 1940 Professor of Law, Northwestern University Law School and Ph.D. student at the University of Chicago's Harris School of Public Policy. I owe thanks to Lee Epstein, Will Howell, and Steve Levitt for their thoughts and ideas. I also thank participants in the University of Chicago Empirical Economics Seminar and the Boston College Law School Tax Colloquium.

${ }^{1}$ Political scientists and students of war define a "major use of force" as instances that involve nuclear capabilities or the mobilization of multiple aircraft carrier task groups, battalions, or combat wings. See William Howell \& Jon C. Pevehouse, President, Congress, and the Use of Force, 59 InTERNAT'L ORG. 209,217 (2005) (describing and defining major and minor uses of force). The major wars of the $20^{\text {th }}$ century include, WWI (1917-18), WWII (1941-45), the Korean War (1950-53), the Vietnam War (196472), and the Gulf War (1990-91). For a discussion of Congress' role in major wars versus minor wars, see William Howell \& Jon C. PeVehouse, When Dangers Gather (2007).

${ }^{2}$ Hannah Fischer, Kim Klarman, \& Mari-Jan Oboroceanu, American War and Military Operations Casualties: Lists and Statistics, CONGRESSIONAL RESEARCH SERVICE (June 29, 2007); see also, Howard Chernik \& Andrew F. Haughwout, Tax Policy and the Fiscal Cost of Disasters: NY and 9/11, 59 NAT'L TAX J. 651 (2006) (discussion of tax costs associated with a direct attack on the nation rather than the deployment of troops); David Karol \& Edward Miguel, The Electoral Cost of War: Iraq Casualties and the 2004 Presidential Election, 69 J. PoL. 633 (2007) (discussion of the political costs of war).

${ }^{3}$ See Center for Strategic Budget Assessments, February 2002 at http://www.csbaonline.org/20061/2.DefenseBudget/Federal_Budget.shtml. The data for fiscal years 1934-07 is based on Department of Defense and Office of Management and Budget data; fiscal years 1910-1933 is based on the Congressional Research Service and Office of Management and Budget data; fiscal year 1910-29 figures are for defense as a share of GNP not GDP. [explain more].
} 
Figure 1: Defense Expenditures as Proportion of GDP

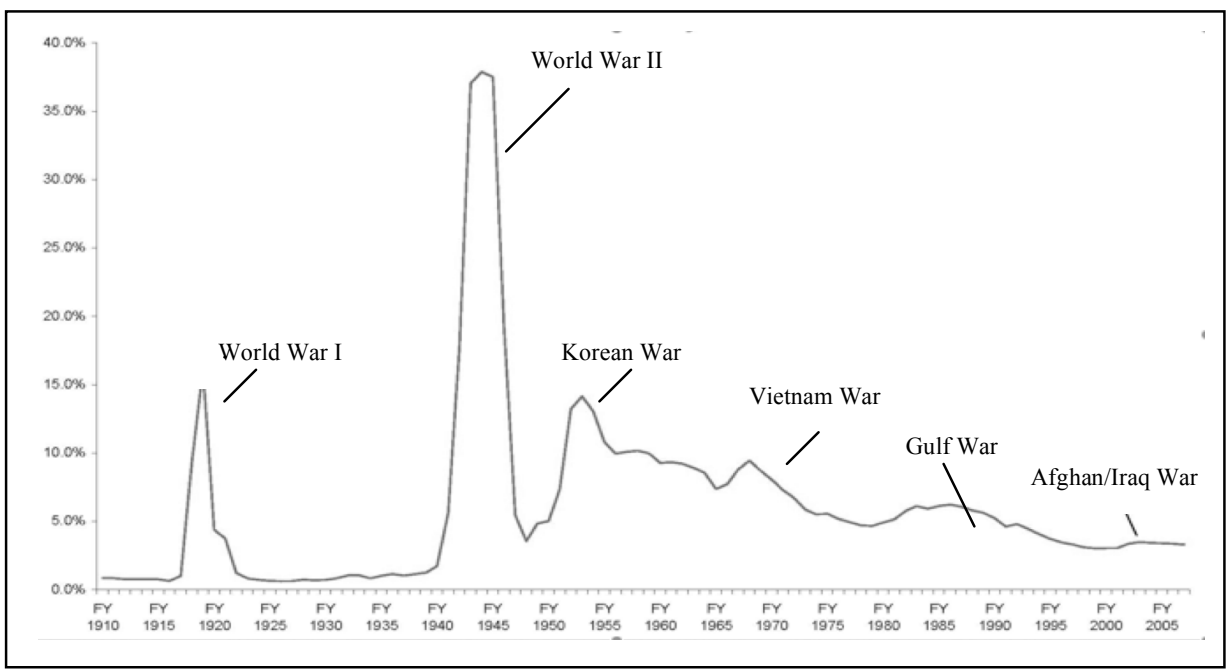

Note: This figure was crafted by the Center for Strategic Budget Assessment (the war signals are mine); the original figure can be viewed at http://www.csbaonline.org/2006-1/2.DefenseBudget/Federal_Budget.shtml.

The fiscal challenges brought about by the first three wars of the $20^{\text {th }}$ century highlight a curious question: How did the U.S. government manage to raise the funds necessary to pay for these expensive and largely unexpected military endeavors? Many economic and legal historians have investigated this question and all provide remarkably similar accounts of fundraising during times of international crises. The authors note that in times of war, the executive and legislative branches tend to set aside ideological and political differences and work quickly and efficiently to raise taxes and implement new rules to preserve national security. ${ }^{4}$ Wars, scholars argue, present the conditions necessary to enable Congress and the President to adopt legislation that greatly expands the existing tax structure; in peacetime, these same reforms would be controversial and could take years to negotiate and ratify-if they get ratified at all..$^{5}$ Because wartime tax policymaking in the early $20^{\text {th }}$ century is so widely perceived to be unique and to have had lasting effects on the law even after the hostilities ceased, scholars argue, "to ignore war is to ignore the single most important influence on the formation and structure of the

\footnotetext{
${ }^{4}$ Scholars that have investigated the affects of war on congressional decision-making include: STEVEN A. BANK, KirK J. StARK, JOSEPH J. THORndike, WAR AND TAXES: Is ThERE AN AMERICAN TRADition OF WARTIME Fiscal SACRIfICE? 2 (2008, forthcoming); John F. WitTE, ThE POLITICS AND DEVELOPMENT OF the Federal Income Tax (1985); W. Elliot Brownlee, Federal taxation in America: A Short History (1996); W. Elliot Brownlee, "Wilson and Financing the Modern State: The Revenue Act of 1916," 129 ProceEdings Of AM. PHIL. SoC. 173-219 (1985); Carolyn Jones, "Class Tax to Mass Tax: The Rise of Propaganda in the Expansion of the Income Tax During World War II," 37 BUFF. L. REV. 685-737 (1989); Mark Leff, "The Politics of Sacrifice on the Home Front in World War II," 77 J. AM. HiST. 129318 (1991); for a general discussion of tax policy making in both the legislative and executive branch, see ThOMAs ReEse, Politics of TAXATION (1980).

${ }^{5}$ BROWNLEE, supra note at 1996, WitTE, supra note at 1985.
} 
tax code" if not the government as a whole. ${ }^{6}$ In the words of Professors Stark, Banks, and Thorndike, "As every student of American taxation knows, war has been the most important catalyst for long-term structural change in the nation's fiscal system. Indeed, the history of America's tax system can largely be written as a history of American wars."

The extant literature on wartime taxation is both rich and nuanced; it enables an understanding of how we obtained the specific legal rules we have, ${ }^{8}$ why government tends to grow with each new crisis, ${ }^{9}$ and when we can expect further ground-breaking policy changes down the road. ${ }^{10}$ The literature, however, has focused entirely on the elected branches of government. Missing from the historical account of tax policymaking during international crises is the third branch of government: the U.S. Supreme Court. Of course, many scholars have investigated whether war affects the judiciary in the context of civil rights and liberties. ${ }^{11}$ In particular, these studies have sought to determine whether the Court is predisposed to sanction laws that constrain individual rights in periods of a national crisis, such as the decision to intern JapaneseAmerican citizens in World War II. ${ }^{12}$ No scholar, however, has studied the Court's response to fiscal questions in times of war. I find the exclusive focus on civil rights somewhat surprising given legislators' obvious belief that tax policy is a key ingredient to assuring success in wartime activities.

Perhaps scholars do not perceive the judiciary to be an important policy player in fiscal emergencies; after all, courts do not have constitutional authority to draft new legislation mandating that individuals or corporations contribute to the federal fisc in times war. ${ }^{13}$ This is a cramped understanding of the Court, however, and one that may

\footnotetext{
${ }^{6}$ WitTE, supra note at 1985; ROBERT HigGS, CRISIS AND LEVIATHAN: CRITICAL EPISODES IN THE GROWTH OF AMERICAN GOVERNMENT (1987) (arguing wars have ratchet-effect by constantly increasing the power of the state)..

${ }^{7}$ BANK, STARK, \& THORNDIKE, supra note at 2.

${ }^{8}$ BANK, STARK, \& THORNDIKE, supra note at 2.

${ }^{9}$ HigGs, supra note at 6

${ }^{10}$ WITTE, supra note at 1985; BANK, STARK, \& THORNDIKE, supra note at.

${ }^{11}$ For just a few examples, see, e.g., Tom Clark, Judicial Decision Making During Wartime, 3 J. LEG. STUD. 397 (2006); Lee Epstein, Daniel Ho, Gary King, \& Jeffrey Segal, The Supreme Court During Crisis: How War Affects Only Non-War Cases, 80 NYU L, REV. 1-116 (2005): 1-116; Joel Grossman, The Japanese American Cases and the Vagaries of Constitutional Adjudication in Wartime: An Institutional Perspective, 19 UnIV. HAW. L. REV. 649 (1997); Neil Katyal \& Lawrence Tribe, Waging War, Deciding Guilt: Trying the Military Tribunals, 111 YALE L. REV. 1259 (2002).

${ }^{12}$ The scholars that have investigated this question in the context of constitutional rights and liberties have reached mixed and often conflicting results. One explanation for the assorted findings in the extant literature is related to the fact that judicial incentive are themselves contradictory in the rights and liberties context and thus it is not only impossible to predict ex ante how wars will affect the justices, but the results themselves are likely to be sensitive to the specific cases analyzed. In the fiscal context, by contrast, there are various judicial incentives at work but all operate in the same direction - and all in favor the government. For this reason, I am able to identify whether war induces the Court to change its behavior as well as why the observed changes occur. See infra notes and accompanying text.

${ }^{13}$ U.S CONST. Art1, $\S 1$ (all legislative power granted in the Congress of the United States). The justices, however, are free to expand and contract the meaning of civil rights and liberties. See, infra notes and accompanying text.
} 
not capture the justices' ability to impact the budget. First, data indicate that the justices tend to grant certiorari to tax cases that have national revenue implications; ${ }^{14}$ the government, itself, often claims that a Court decision on behalf of the taxpayers in the cases it litigates could have detrimental budgetary consequences. ${ }^{15}$ Second, the justices have the power to create rules and standards that favor the government, and thus are capable of contributing to war funding by increasing the number of pro-government decisions in times of crisis. ${ }^{16}$ In contexts outside fiscal policy, scholars have argued that the justices - rightly or wrongly - do adopt a pro-government stance in times of war, thereby enabling Congress and the President far more independence and freedom to address the emergency at hand. ${ }^{17}$ The U.S. Supreme Court, in short, is institutionally capable of engaging in the same type of fiscal activities that tax scholars have long observed in the elected branches; whether it chooses to do so is an empirical question.

In this essay I take up this question and seek to identify the effects, if any, that war has on judicial tax decisions. ${ }^{19}$ For purposes of this investigation, I do not examine the specific doctrinal rules that emerge during wartime but rather focus on the proportion of pro-government outcomes in the cases decided. As I discuss below, if national crises do

\footnotetext{
${ }^{14}$ Nancy Staudt, Agenda Setting In Supreme Court Tax Cases: Lessons From the Blackmun Papers, 52 BUFF. L. REV. 889 (2005)

${ }^{15}$ Staudt, supra note at ; see also Sup. Ct Rules $\S$ (indicating that the Court should grant certiorari to cases with national implications and this includes budgetary issues).

${ }^{16}$ Nancy Staudt, Lee Epstein, Peter Weidenbeck, Rene Lindstaadt, and Ryan Vender Weilen, Judging Statutes, Interpretive Regimes, 39 LOY. L. REV. 1909 (2005).

${ }^{17}$ See, e.g., Norman Dorsen, Foreign Affairs and Civil Liberties, 83 AM. J. INT'L L. 840 (1989).

19 The notion that the justices should or would have different conceptions of the law during wartime than in peacetime is unambiguously a controversial proposition. As I note below, some argue that the justices have an obligation to facilitate successful wartime policymaking and thus must defer to Congress the executive in times of emergency even if this means setting aside existing standards of law and accepted modes of legal interpretation. Others argue the Court should not defer to national emergency measures, but rather subject them to heightened scrutiny precisely because society is more apt tolerate transgressions with respect to basic individual rights and entitlements during times of crisis. I do not take a normative position on this question. Of course, every Court and every justice need not have the same view on this question; Silverstein notes that the Court has not taken a consistent position on the matter in the constitutional context. In some eras, the justices have enforced limits on the government's ability to curb individual rights and liberties while at other times the Court has been more lenient and has allowed the national government to infringe on civil rights especially when the laws are very specific to the circumstances and hand and are written as narrowly as possible. SILVERSTEIN, 107-118.
} 
alter the judicial calculus in the fiscal context, I expect the justices will reach a higher number of pro-government decisions during the wartime periods than we expect on average. $^{20}$ War may impact the judiciary in many other ways but for now I limit my focus to this specific issue. ${ }^{21}$

This essay is organized as follows. Section II describes Supreme Court decisionmaking in the context of taxation over the course of the last century. The important and notable trend, for purposes of this study, is the fact that the justices rule in favor of the U.S. government in the vast majority of cases $-70 \%$ on average. The raw data, however, indicate this average tends to increase in wartime and decrease in peacetime. Section III, therefore, investigates possible explanations for the heightened deference to the government in times of war. One potential rationale for the observed change in judicial behavior is a perceived imbalance in military expertise. If the justices believe the elected branches of government are better-suited to address military crises, the Court is likely to adopt a pro-government bias as a means to advance the decisions and policies of the experts. This support for the national government in times of war, in turn, could lead to the Court to defer to Congress and the President in all the cases involving the national government or to a more restricted deference that leads to accommodation only in specific cases involving issues deemed key to a successful wartime strategy. A second potential explanation for the justices pro-government stance may not be associated with the belief that the elected officials are more competent to address the crisis at-hand, but due to feelings of heightened nationalism that citizens tend to experience when the country is threatened by forces abroad.

These motivations might work singly or in combination with each other, but it is worthwhile to examine all three in order to understand fully the factors that explain how and why the justices contribute to wartime funding. Accordingly, Section IV further examines the data in an effort to identify the actual mechanism at work. Section IVA discusses three simple statistical models that I will use to understand why the justices change their behavior from wartime to peacetime; Section IVB discusses the underlying assumptions of the models and possible biases; and Section IVC presents the empirical findings.

After controlling for possible confounding factors, I find that the justices in fact do defer to the federal government in tax cases during wartime periods and that the most likely explanation for this deference is not associated not with an irrational exuberance for federal policymakers in times of crisis, but to the perceived imbalance in expertise when it comes to military matters. The inclination to accommodate, however, does not lead to the maximum possible level of deference to the government in tax cases, but rather to a limited form; the Court does not increase the number of pro-government decisions across-the-board, but only in cases raising issues that Congress and the President have signaled to be important to the war through legislative activity.

\footnotetext{
${ }^{20}$ A qualitative analysis of the specific rules that emerge during wartime would be a very interesting and useful endeavor but is beyond the scope of this article.

${ }^{21}$ War, for example, may impact the size of the docket or the Court's approach to statutory interpretation.
} 
These findings seriously challenge the conventional views of the role of Supreme Court justices in both our system of separated powers and in national policymaking. First, the generally held view of the Court is that justices stand above majoritarian politics and thus operate as a check on the extremist policies that can (and often do) emerge from the elected branches of government. This conception of the Court appears to hold only during peacetime periods; during wartime, the justices are willing to unleash Congress and the President from the constraints associated with judicial review, thereby enabling them to exercise quite a bit more freedom and autonomy to address the international crisis at-hand. Second, these findings suggest that the justices believe the effects of their decisions go well beyond the individual litigants in the case; indeed, the justices seem to shift their focus from one that protects the micro-level rights and interests of individual taxpayers to macro-level policies that implicate the nation as a whole. This judicial transformation raises the question of whether the justices have similar macro-level views when domestic emergencies arise, such as those involving economic crises, housing crises, immigration crises, or old-age crises.

\section{TRENDS IN JUdicial Fiscal Policy}

The United States spent seventeen years, or nearly one-fifth of the entire Twentieth Century, engaged in five major military activities at a cost of nearly $\$ 5$ trillion. $^{22}$ In order to understand the judicial response to these wartime costs, it is worthwhile to examine briefly just how the wars affected fiscal policymaking in the elected branches of government. After all, if Congress, the President, and the nation atlarge did not consider wartime costs to be a pressing national concern, then it is unlikely that the justices would modify their own decision-making calculus when issuing opinions in the tax cases that emerged onto their docket.

Countless economic historians have studied the effects of war on legislative tax policymaking, including Joseph Shumpeter, Randolph E. Paul, Sidney Ratner, Elliot Brownlee, John Witte, Robert Higgs and most recently Steven Banks, Kirk Stark, and Joseph Thorndike - to name just a few. ${ }^{23}$ With the help of both theory and data, each of these authors, or teams of authors, have made important contributions to our understanding of wartime legislative fiscal decisions. ${ }^{24}$ Surprisingly, the scholars all tell very similar stories about how tax policy is made as well as the changes in the fiscal

\footnotetext{
${ }^{22}$ The major wars of the $20^{\text {th }}$ century include, WWI (1917-18), WWII (1941-45), the Korean War (195053), the Vietnam War (1964-72), and the Gulf War (1990-91). See supra note and accompanying text.

${ }^{23}$ JOSEPH SHUMPETER, RANDOLPH PAUL, SidNEY RATNER, BROWNLEE, supra note at ; WiTTE, supra note at; HigGS, supra note at, BANKS, STARK, \& THORNDIKE, supra note at

${ }^{24}$ These authors have primarily relied on qualitative data for purposes of understanding the decisions that Congress and the President have made and for this reason much more work must to be done before we can understand fully the nature and role of military threats, politics, and economics on wartime decisionmaking. For purposes of this study, however, I set aside the interesting quantitative questions and simply offer a brief summary of what is by now a familiar story on how the American government has paid for its wartime endeavors.
} 
framework that emerged in each wartime era. Congress and the President increased tax rates in World War I, World War II, and the Korean War to conspicuously high levels in an effort to fund the extraordinary and unexpected costs of national defense. ${ }^{25}$ The elected officials also increased taxes during the Vietnam and Gulf Wars, but not immediately and not to the same extreme levels observed in earlier war periods. ${ }^{26}$ Scholars also note, however, that when Congress and the President looked to the taxpayers as a revenue source, the reforms were not always identical. In WWI, for example, Congress relied heavily on corporate entities; ${ }^{27}$ in WWII and the Korean War, Congress increased the tax burdens on both corporations and individuals, but relied quite a bit more on individual taxpayers as a source of revenue; ${ }^{28}$ and in the Vietnam and Gulf Wars, Congress raised individual tax rates to a far greater extent than corporate rates but the reforms were relatively minor compared to those adopted in earlier periods and may not have been motivated by wartime fiscal pressures at all.

Figure 2 presents data on the level of corporate and individual tax receipts as a percentage of the GDP over the course of the Twentieth Century and reflect the congressional decisions made in each wartime era. ${ }^{29}$ The grey trend-line reflects corporate tax receipts and the black trend-line indicates individual receipts as a proportion of the GDP in each year. It is easy to see that Congress relied on different groups to different degrees in WWI, WWII, and the Korean War, but that no obvious reforms are correlated with the Vietnam or Gulf Wars.

The question I investigate is whether these wartime reforms had any effect on Supreme Court decision-making. The justices, of course, have no direct involvement in determining just how the country funds wartime activities, but they are indirectly involved when they issue opinions that address taxpayer obligations during the crisis periods. In fact, between the years 1909 and 2000, the time period of this study, Congress voted on roughly 2,000 tax bills while the justices issued opinions in 1,113 tax cases. This suggests that while Congress was busy drafting the laws, the Supreme Court was busy interpreting them in the context of disputes that made their way onto the docket. $^{30}$

\footnotetext{
${ }^{25}$ BROWNLEE, supra note at ; WITTE, supra note at; HigGS, supra note at, BANKS, STARK, \& THORNDIKE, supra note at

${ }^{26}$ BANKS, STARK, \& THORNDIKE, supra note at

${ }^{27}$ BROWNLEE, supra note at ; WITTE, supra note at; HigGS, supra note at, BANKS, STARK, \& THORNDIKE, supra note at

${ }^{28}$ BANKS, STARK, \& THORNDIKE, supra note at

${ }^{29}$ This graph is an updated version of a graph originally created by John Witte, see WITTE, supra note. See also U.S. Census Bureau, Statistical Abstracts: Historical Statistics (2007) (underlying data on tax receipts by year) available at http:/www.census.gov/compendia/statab/hist_stats.html; LOUIS JOHNSTON \& SAMUEL WILLIMASON, U.S. GDP, 1789-2002 available at http://eh.net/hmit/gdp/GDPsource.2003.htm (for underlying GDP data).

${ }^{30}$ The study begins with the year 1909 because this is the year in which Congress adopted the modern corporate income tax; four years later, Congress adopted the modern income tax has not substantially changed the structure of the tax since that time. See [Code cites]. The Lexis search that we conducted read as follows: (federal w/s tax!) or (excise w/s tax!) or (estate w/s tax!) or (user w/5 fee) or (user w/s tax!) or (tax! w/s fraud) or (irc) or (i.r.c.) or (stamp w/s tax!) or (income w/s tax!) or (internal w/s revenue) or (tax! $\mathrm{w} / \mathrm{s}$ lien) or (tax! w/s code) or (tax! w/s evad!) or (tax! w/s evasion) or (corporate w/s tax!) or (payroll w/s
} 
Figure 2: Corporate \& Individual Tax Receipts as Percentage of GDP

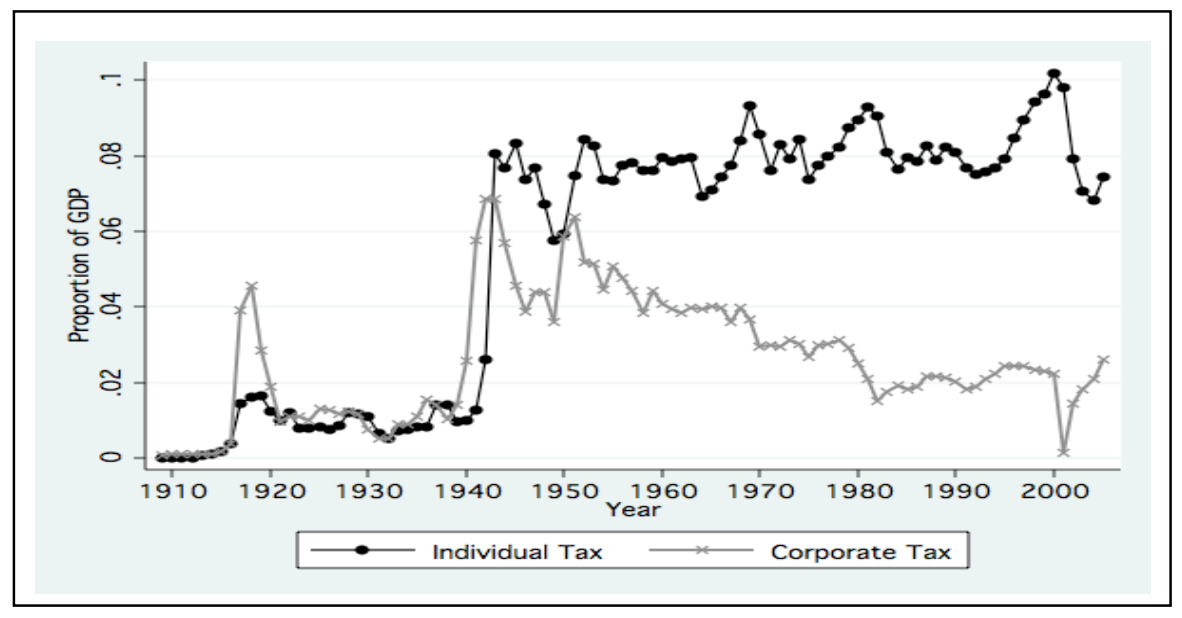

*Note: This graph is an updated version of a graph created by John Witte.

For purposes of this study, I examine the 1,113 Court opinions issued during the Twentieth Century and compare outcomes in wartime versus peacetime. In order to understand the underlying my goals, it is useful to conceptualize this study as a "quasiexperiment." Just as medical studies seek to identify the effects, if any, of a treatment on the outcome of a patient-I seek to identify whether war has any effects on judicial outcomes. Economists label this type of study a "natural experiment" or a "quasiexperiment" because the treatment (the war) emerged through exogenous circumstances. ${ }^{31}$ In a true experimental setting, the researcher generally assigns subjects randomly into two (or more groups) and then applies the treatment to one group and uses the other as a control or comparison group. ${ }^{32}$ Obviously, I did not randomly divide the justices into two groups and then impose wars on one group and not the other in order to investigate how the justices would respond. Rather the wars emerged from a combination of national and international and factors that had nothing to do with the justices and everything to do with the preferences of the sitting Congress and President at the time the crisis emerged. ${ }^{33}$ Nonetheless, I am able to take advantage of these conditions for purposes of identifying and understanding the effects of war on the Supreme Court decision-making process. ${ }^{34}$ I will address the advantages and possible disadvantages of this natural experiment further below, but before that discussion, I describe the characteristics of the tax cases decided by the Court. ${ }^{35}$

tax!) or (employment w/s tax!) or (social w/s security) or (26 usc) or (26 u.s.c.) or (tax! w/s refund) or (tax! $\mathrm{w} / \mathrm{s}$ deficiency) or (unemployment w/s tax!) or (gift w/s tax!) or (fica w/s tax!) or (f.i.c.a. w/s tax!).

${ }^{31}$ See Bruce Meyer, Natural and Quasi-Experiments in Economics, 13 J. Bus. \& ECON. STATS. 151 (1995).

${ }^{33}$ See infra notes and accompanying text (discussing legislative and executive war powers.)

${ }^{34}$ Many scholars look to natural or quasi-experiments for purposes of understanding the affects of one variable on another. See, e.g., DAVid CARD \& Alan Kreugger, Minimum Wage (2000).

${ }^{35}$ Many scholars investigating the effects of war on courts also have a natural experiment, but do not frame the issue as such. See, Clark, supra note at. Others, however, adopt a different methodological approach to 
As noted above, between the years 1909 and 2000, the Court granted certiorari to 1,113 cases in which taxpayers challenged tax laws as unconstitutional or simply as misinterpreted by the Internal Revenue Service. Although roughly 5\% of the Court's docket has been comprised of taxation cases throughout the period of this study, the actual number of cases has fluctuated quite a bit each term. At the highpoint of tax decision-making, the 1930s, the Court issued 386 tax opinions but both before and after that time the justices granted certiorari to far fewer cases. In fact, after the 1930s, the tax caseload was on a downward trend and by the 1950s the number of federal tax cases on the docket leveled off to approximately five controversies per term. Figure 3 depicts the distribution of the cases (the shaded areas represent wartime periods) and indicates the spike in the Court's caseload in the1930's but no similarly dramatic spikes in other eras, wartime or peacetime.

Figure 3: Frequency of Tax Cases on the Supreme Court Docket

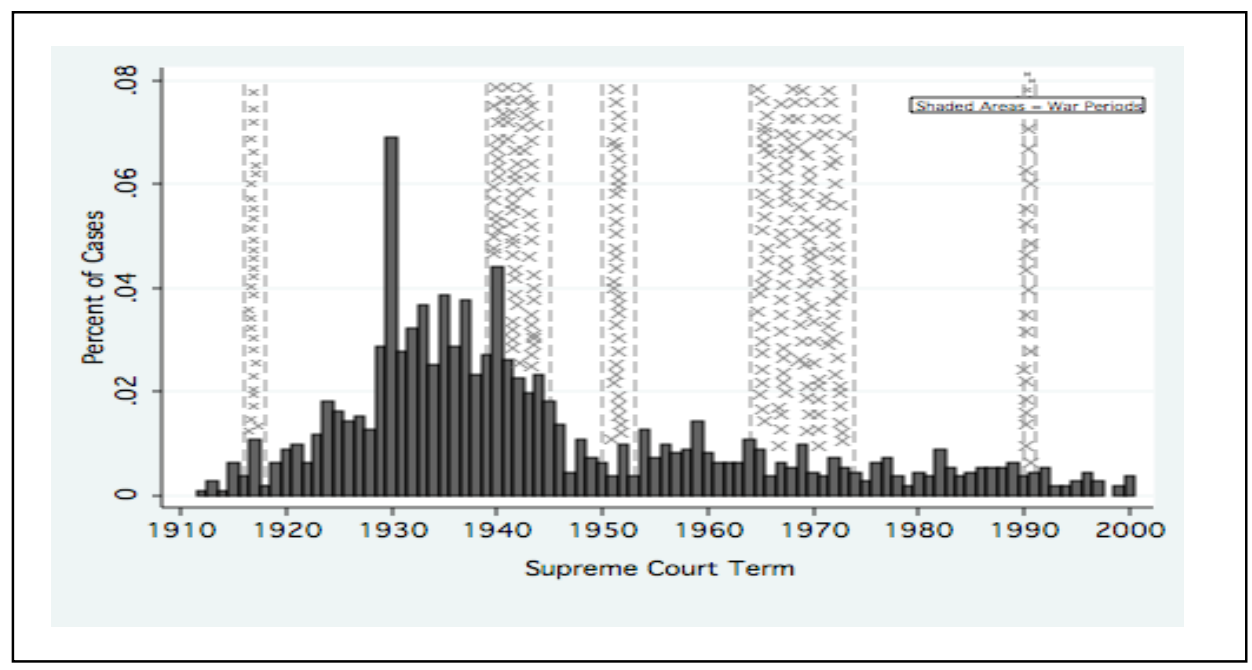

After collecting the data, I analyzed each case individually and identified a wide range of factors, including: 1) the type of party involved in the case (corporate, individual, estate and so forth), 2) the Court's reason for granting certiorari, 3) the Court's interpretive approach for deciding the case, 4) the complexity of the case, 5) the level of media coverage, 6) the Court's ideology at the time it issued the opinion, and 7) the prevailing party in the lower federal court. My coding decisions are explained in the appendix and the statistics are summarized in Table 1 below. Column 2 in the Table presents the average of each case characteristic over the entire period of the study, and Columns 3 and 4 disaggregate this information, depicting case characteristics in wartime and peacetime, separately. All the cases, for example, raised a statutory claim so there is literally no difference between the cases on this dimension. Looking further down the table, we can see that the justices granted certiorari in $7 \%$ of all the cases to address an 
"important question, but this number increased to $9 \%$ in wartime and decreased to $6 \%$ in peacetime.

In order to conduct a valid natural experiment and to make useful comparisons between cases decided in peacetime and wartime, it is important that that the two groups of cases (the control group and the treatment group) are similar on all relevant facets. Accordingly, I have bolded the case characteristics that are statistically and significantly different during peacetime and wartime; that is to say, we can say with $95 \%$ confidence that the wartime and peacetime cases differed on the bolded factors but we cannot reject the null hypothesis that the cases are the same on the factors left unbolded. ${ }^{36}$ Table 1 indicates that the cases are nearly identical in 10 of the 13 categories listed; the primary differences, include the number of constitutional claims alleged- $-10 \%$ during wartime and $15 \%$ in peacetime; the number of individual taxpayers involved in the lawsuits $-23 \%$ in wartime and $18 \%$ in peacetime; and the Court's ideology-liberal in both periods but quite a bit more liberal in wartime than peacetime. I discuss these differences further below, as well as their implications for this study, ${ }^{37}$ but for now I simply present a summary of the dataset.

Table 1: Summary Statistics of Supreme Court Tax Cases

\begin{tabular}{lccc}
\hline \hline \multicolumn{1}{c}{ Variable } & All & Wartime & Peacetime \\
& Cases & Cases & Cases \\
& $N=1,113$ & $n=277$ & $n=833$ \\
\hline \hline Statutory Claim & $100 \%$ & $100 \%$ & $100 \%$ \\
Constitutional Claim & $\mathbf{1 4 \%}$ & $\mathbf{1 0 \%}$ & $\mathbf{1 5 \%}$ \\
Corporate Taxpayers & $35 \%$ & $34 \%$ & $35 \%$ \\
Individual Taxpayers & $\mathbf{1 9 \%}$ & $\mathbf{2 3 \%}$ & $\mathbf{1 8 \%}$ \\
Other Taxpayers & $46 \%$ & $44 \%$ & $47 \%$ \\
Court's Ideology(negative score=liberal) & $\mathbf{- . 2 2 0 3}$ & $\mathbf{- . 3 5 4 2}$ & $\mathbf{- . 1 2 8 4}$ \\
Judicial Reliance on Substantive Methods & $47 \%$ & $49 \%$ & $46 \%$ \\
Judicial Reliance on Textual Methods & $38 \%$ & $37 \%$ & $38 \%$ \\
Taxpayer Won in Lower Federal Court & $54 \%$ & $55 \%$ & $53 \%$ \\
Media Coverage & $4 \%$ & $5 \%$ & $3 \%$ \\
Certiorari to Resolve "Important Question" & $7 \%$ & $9 \%$ & $6 \%$ \\
Certiorari Granted Without Explanation & $45 \%$ & $42 \%$ & $49 \%$ \\
Cases with Just One Issue & $92 \%$ & $91 \%$ & $93 \%$ \\
\hline \hline
\end{tabular}

* Note: Statistics indicate percentage of cases in dataset with the exception of the "Court's Ideology" where the mean ideology score is presented. Variables that are bolded indicate a statistically significant difference between wartime and peacetime with a p-value $<.05$.

\footnotetext{
${ }^{36}$ To determine whether a statistically significant difference exists during wartime and peacetime, I used a difference in proportions test for the all the variables except the Court's ideology, for which I used a t-test. The difference in proportions was determined in the following way: $\hat{\pi}_{1}-\hat{\pi}_{2} / \sqrt{\hat{\pi}_{1}\left(1-\hat{\pi}_{2}\right)\left(1 / n_{1}+1 / n_{2}\right)}$ where subscript 2 denotes wartime, subscript 1 denotes peacetime, and $\pi$ is the percentage of the variable that obtains in each era. See BinARY AND Discrete VARIABLES (2000) (useful discussion of statistical analysis of binary data.

${ }^{37}$ See infra notes and accompanying text.
} 
The variables examined in Table 1 are important (as I discuss further below) but the specific variable of interest in this study is the government win-rate. On average, the U.S. government wins the vast majority of tax cases that it litigates in the Supreme Court-70\% - but this percentage decreases to $68 \%$ in peacetime and increases to $73 \%$ during wartime. Figure 3 depicts the percentage of cases in which government prevails over each Supreme Court term from 1909 though 2000, using a lowess smother. ${ }^{38}$ The yaxis indicates the percentage of pro-government decisions and the $\mathrm{x}$-axis is the Supreme Court term; shading indicates the Court issued the opinion in a wartime period. Note the spikes in the early wartime periods, WWI, WWII, and the Korean War, suggesting that war is indeed affecting the justices' decision-making process. There is a small increase in the number of pro-government decision in the Vietnam War but no such trend in the Gulf War. Figure 3 also depicts non-wartime spikes and most notably a spike in the late 1920s and early 1930s; this suggests that the Court may not be responsive only to wars, but to any major crisis that emerges, whether domestic or foreign in nature.

Figure 4: Government Win Rate Over Time

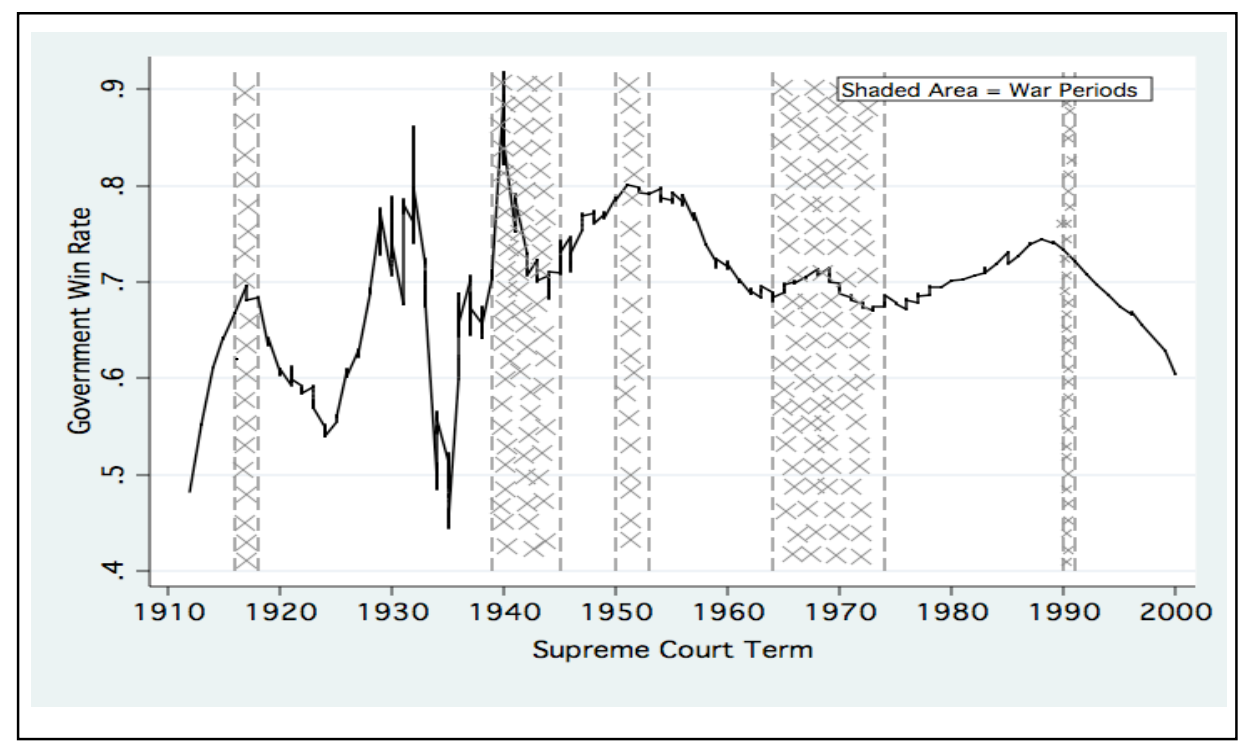

* Note: Graph depicts government win-rate using the lowess technique. The bandwith is 0.1 (which states that the smoothing window has a total width of $10 \%$ of the horizontal axis variable) and thus the lowess curve follows the individual data points closely.

Figure 3 illustrates government's win-rates in the aggregated data, but it is also possible to examine different types of cases and parties separately. As indicated in the summary statistics in Table 1 above, the two largest groups of taxpayers that brought claims to the Supreme Court were corporate entities and individuals challenging the income tax. Moreover, Congress focused on each of these two groups to different degrees in each wartime period as Figure 2 indicates. Thus if the Court pays any attention to the specific type of reform implemented by the elected branches of

\footnotetext{
${ }^{38}$ Lowess is an acronym for "locally weighted scatterplot smoother" and is a procedure used to examine trends in the data over time. For a discussion of this procedure, see JOHN FOX, APPLIED REGRESSION ANALysis, LineAr Models, AND RELATED Methods 419-24 (1997).
} 
government, we might expect to observe corporate and individual taxpayers treated differently in each wartime period.

The raw data indicates that corporations and individuals win, on average, just .3 of the cases they litigate in the Supreme Court. These averages, however, change dramatically if we condition the five different major wartime periods of the Twentieth Century. Table 2 presents a comparison of the government win-rates vis-à-vis corporate and individual taxpayers in different eras. The first row indicates that the government won $67 \%$ of the corporate cases and $68 \%$ of the individual cases during peacetime. Row 2 depicts dramatic shifts in these win-rates during WWI - the government won $80 \%$ of the corporate cases and just $29 \%$ of the individual cases. In WWI, the trend shifted and the government won $64 \%$ and $84 \%$ of the corporate and individual cases, respectively. The Korean War showed an even lower corporate win-rate of 33\% and a 70\% win-rate in the individual taxpayer context. During the Vietnam War, the government won a high percentage of the cases in both groups, $76 \%$ and $77 \%$, respectively. Finally, the Court decided just one tax case during the Gulf War and the government prevailed. These trends do not appear to be random, all the wartime win-rates are statistically significantly different from the peacetime averages. Thus we can conclude that based on very preliminary findings, wartime crises are leading the Court to act very differently than it does in peacetime.

Table 2: Comparison of Wartime \& Peacetime Courts by Taxpayer-Type

\begin{tabular}{lcc}
\hline \hline & Government Win Rates & \\
\hline \hline \multicolumn{1}{c}{ Period } & Corporate Taxpayer & Individual Taxpayer \\
& Cases & Cases \\
& $N=388$ & $N=215$ \\
\hline \hline Peacetime Average & $67 \%$ & $68 \%$ \\
WWI & $\mathbf{8 0 \%}$ & $\mathbf{2 9 \%}$ \\
WWII & $\mathbf{6 4 \%}$ & $\mathbf{8 4 \%}$ \\
Korean War & $\mathbf{3 3 \%}$ & $\mathbf{7 0 \%}$ \\
Vietnam War & $\mathbf{7 6 \%}$ & $\mathbf{7 7 \%}$ \\
Gulf War & $\mathbf{0 \%}$ & $\mathbf{1 0 0 \%}$ \\
\hline \hline
\end{tabular}

* Note: All the bolded wartime government win-rates are statistically significantly different from the peacetime averages with a p-value $<.05$.

The raw data presented in the Figures and Tables above suggest several factors about legislative and judicial decision-making trends in peacetime and wartime. First, the three major wars in the early Twentieth Century, WWI, WWII, and the Korean War, led Congress and the President to adopt quick and dramatic tax reforms, but no such extraordinary legal changes emerged in either the Vietnam or Gulf Wars. Second, taxpayers litigate quite a few controversies in the Supreme Court and while the claims, parties, interpretive methods, and so forth are all very similar in both wartime and peacetime, the government win-rates differed significantly in each period. Third, foreign crises do not always lead the Supreme Court to issue to pro-government opinions, rather the outcome appears to be linked to the specific party involved and perhaps to the specific type of legislation adopted by Congress prior to the time the litigation started. 
Most legal scholars believe the Supreme Court is an independent body of decision-makers, ${ }^{39}$ designed by the Framers to act in a manner that is both separate and apart from the elected branches of government. Indeed, many scholars have argued that for the Supreme Court justices to conform their decisions to the preferences of Congress and the President is tantamount to the Court failing in its constitutional obligation to protect individuals from the extremist laws that are likely to emerge in the democratic process. ${ }^{40}$ Why, then, would the justices transform their choice calculus to account for the actions of the majoritarian bodies in times of war, thereby undermining their role as an independent body in our system of separated powers? In the next section, I investigate this question and identify various judicial incentives that could explain the trends observed above.

\section{Judicial Incentive Structures in Wartime And Peacetime}

Many scholars have investigated the effects of war on Supreme Court justices. ${ }^{41}$ All the studies, however, focus on judicial decisions that involve individual civil rights and liberties and none seek to understand whether war plays a role in the judicial fiscal context. One famous case, for example, that has received quite a bit of attention is Korematsu v. United States, ${ }^{42}$ which considered President Roosevelt's executive order allowing local military commanders to forcibly remove and intern Japanese and Japanese Americans from the West Coast during World War II. Fred Korematsu refused to obey the order arguing internment violated his rights under the constitution, but the justices found that no such violation had occurred. ${ }^{43}$ Various scholars argue that the justices found a violation only because of the looming crisis, whereas others argue the justices were not at all impacted by the international threats that existed at the time. ${ }^{44}$ Professors Epstein, Ho, King, and Segal's study, the only large- $N$ quantitative study of the question, supports the latter viewpoint. ${ }^{45}$ I do not seek to arbitrate between these two views but only to point to the fact that the existing literature has focused entirely on Supreme Court cases involving constitutional rights and liberties and has completely disregarded all other types of wartime decision-making, such as the cases involving public finance. I find the exclusive focus on rights and liberties surprising given that Congress and the President have long viewed fiscal policy to be a key component of a winning military strategy. In fact, various studies suggest that the most controversial aspects of wartime

\footnotetext{
${ }^{39}$ In both the law and political science literature, most scholars seem to suggest that the Supreme Court (whether driven by politics, law, or some combination of the two) behaves in a manner that is separate and apart from the legislative and executive branches of government. [List authors]

${ }^{40}$ See discussion, infra notes and accompanying text.

${ }^{41}$ See supra note; see also, Epstein, Ho, King, and Segal, supra note at notes 13 \& 14 (listing numerous books and articles on the topic).

42323 U.S. 214 (1944).

43323 U.S. 214, 219-20 (1944) (Court acknowledged that the U.S. government imposed serious hardships on Japanese-American citizens, but noted that in wartime citizens must submit to heavy burdens that are commensurate with the threatened danger). 44

${ }^{45}$ Epstein, Ho, King, and Segal, supra note.
} 
decision-making in Congress involve the funding mechanisms and not the initial decision to go war. More fundamentally, it is likely that the conclusions in the extant literature with respect to rights and liberties are not generalizable to all other legal contexts, especially those involving taxation.

In this Section, I explain why the justices may have very different incentive structures in civil rights/liberties cases than in tax cases. I then examine various judicial incentives that exist and explain their impact on the government's likelihood of winning a tax case in wartime versus peacetime. I find the pro-government incentives are quite a bit stronger in controversies involving fiscal policy than those involving civil rights and liberties cases and thus I expect a stronger correlation between wartime decision-making and government success than identified in the extant literature.

\section{A. Incentive Structures in Constitutional and Statutory Cases: Distinctions that Matter.}

In order to understand judicial incentive structures and how they might impact outcomes, it is important to understand key differences between civil rights-type cases, which generally involve constitutional questions, and tax cases, which generally involve issues of statutory interpretation. ${ }^{46}$ Because these cases raise very different issues, the justices have distinct decision-making procedures in each context and this, in turn, could lead to different wartime effects in the two contexts.

In the constitutional context, the Court is faced with the question of whether or not Congress or the President has overstepped the bounds of power as spelled out in the Constitution. In these types of cases, the Court is the final arbiter and, at least in theory, the other two branches of government have no recourse whatsoever. ${ }^{47}$ Put differently, if the Court declares an action, decision, or order to be unconstitutional then Congress and/or the President must suspend the program or policy. ${ }^{48}$ More directly, if the justices determined the presidential order permitting the internment of Japanese-Americans to be a violation of individual rights and liberties, the military commanders would have been forced to dismantle the camps immediately. Fred Korematsu's criminal conviction for violating the military order to evacuate his hometown and report to a military center would have been overturned by the Supreme Court.

\footnotetext{
${ }^{46}$ Although it is certainly possible that civil rights cases involve issues of statutory interpretation and tax cases involve constitutional questions, this is not the norm. In my dataset, for example, the Court issues 1,113 decisions and just $14 \%(n=156)$ raised one or more constitutional issues. Additionally, constitutional and statutory issues are not mutually exclusive. In the 1918 case, Towne v. Eisner, the Court considered the question of whether a new income tax provision was constitutional and even if it was, if it could be interpreted to impose a tax only on earned income (such as wages or salary) or whether the statute should be read broadly to tax unearned income (such as stock dividends). Towne v. Eisner, 245 U.S. 418 (1918). ${ }^{47}$ Some scholars argue that while it is true the justices have the last word on the constitutionality of a law, legislators are able to punish the justices in various ways if their decisions do not conform to congressional preferences the preferences. See LeE Epstein \& JACK KNight, The Choice Justices Make (1995). Threatened sanctions, in turn, induce justices to change their views in some circumstances. But see, Jeffrey

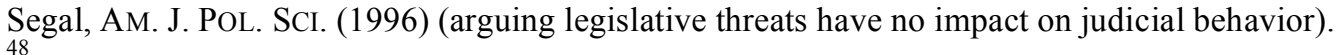


In the statutory interpretation context, by contrast, the justices are only required to resolve the question of whether and how a particular statute should govern the parties and transactions in the controversy at hand, there is no question that the elected branches of government acted with the bounds of their constitutional authority. ${ }^{49}$ Taxpayers raising statutory claims, for example, will argue that the tax laws, as currently written do not impose the tax burden alleged to exist by the IRS; the IRS simply misunderstood or misinterpreted the statute. Most importantly for purposes of this study, Congress and the President are not obligated to adhere to the Court's decision in a statutory case. Irrespective of the Court's determination in the case, regardless of the legal grounds relied upon, and whether or not the decision favors the taxpayer or the governmentlegislators are completely free to overturn the Court's ruling. ${ }^{50}$ In fact, Congress has disagreed with judicial interpretations of the tax law in the past and has responded with legislative overrides in cases such as Gitlitz v. Commissioner ${ }^{51}$ Commissioner v. Lundy, ${ }^{52}$ Commissioner v. Soliman, ${ }^{53}$ and Commissionerr v. Asphalt, ${ }^{54}$ to name just a few. ${ }^{55}$ As noted above, the elected branches of government do not have this freedom in constitutional cases - they are obligated to adhere to the Court's ruling.

This difference is important for purposes of understanding judicial incentives for accommodating or constraining Congress and the President in wartime. In the constitutional context, the Supreme Court, as the third branch of government, is responsible for assuring that Congress and the President do not violate individual rights and liberties at any time - including during periods of international emergencies. In peacetime and in wartime, the justices must assure that the elected branches of government obey the constraints as set out in the U.S. Constitution. In short the constitutional provisions - as the Framers' drafted them - apply whether or not there is a declaration of war. In statutory contexts, by contrast, the Court's responsibility is very different and far more deferential to the elected branches of government. The justices' sole goal is to ascertain the meaning of law as adopted by Congress and then to apply it to the taxpayers in Court. To put the distinction between constitutional and statutory cases in the most extreme form: In constitutional cases, the justices' goal is to implement the preferences of the Framers while in statutory cases the justices seek to execute the preferences of the legislative and executive branches of government.

That the justices' role in statutory cases is to facilitate the aims and goals of the majoritarian bodies - and not second-guess them - suggests that the Court will generally issue rulings favorable to the U.S. government. In fact, as noted above, the government does win the vast majority of tax cases that it litigates in the Supreme Court. But this fact

49

${ }^{50}$ See Nancy Staudt, Rene Lindstadt, and Jason O'Connor, Judicial Decisions as Legislation:

Congressional Oversight of Supreme Court Tax Cases, 1954-2004 NYU (2007)

${ }^{51} 531$ U.S. 206 (2001).

52516 U.S. 235 (1996).

53 506 U.S. 168 (1993).

${ }^{54} 482$ U.S. 117 (1997).

${ }^{55}$ Staudt, et al, supra note at.. 
does not answer the question posed, namely, do the justices read and interpret the tax laws during times of war in a manner that changes the probability that the U.S. government will prevail? The description of the data in Section I above suggests that the government win-rates do change when the country moves into a period of international crisis; I now seek to unpack the incentives that explain this change.

\section{B. Unpacking Judicial Incentives (and Disincentives) to Defer.}

The justices have both incentives and disincentives to accommodate the majoritarian branches of government in times of war. The extant literature has identified three incentives and two disincentives that are the most salient for understanding judicial decision-making. ${ }^{56}$ I discuss each separately and note that judicial preferences will lead the Court to defer to the federal government quite a bit more in statutory cases and less in controversies that raise constitutional questions. ${ }^{57}$ If my analysis is accurate, we should observe different outcomes in constitutional and fiscal decision-making in times of war. This means that the existing findings in the quantitative literature do not have external validity (they are not generalizable to all areas of the law) and thus empirical studies of unique legal areas are necessary before we can understand fully how war affects Supreme Court justices.

Beginning first with the judicial incentives to defer in times of war. To understand these incentives, it is useful to note that the Constitution, itself, implies that the Supreme Court justices should not directly involve themselves in the wartime decision-making process. The Framers, for example, explicitly granted war powers to the executive and legislative branches of government but were completely silent with respect to the judiciary. Specifically, Article I of the Constitution grants Congress the power "to declare War" and "raise and support armies." Similarly, Article II provides that the President "shall be the Commander in Chief of the Army and Navy.",59

Many scholars have argued that Articles I and II-along with the absence of any language suggesting the Court has a role to play in wartime activities - indicate that the Framers viewed the elected branches of government as better equipped to handle national emergencies than the justices on the Supreme Court. ${ }^{60}$ At times, the justices themselves have expressed agreement with this view of their role in wartime policymaking. In Hirabayashi v. United States, for example, the Court wrote that the federal government's "power to wage war is the power to wage war successfully," suggesting that the justices must not interfere in any way with the other two branches of government as they seek to execute a successful military strategy. ${ }^{61}$ Similarly, in Licheter v. US, Justice Burton

\footnotetext{
${ }^{56}$ The best description of the incentives can be found in Epstein, Ho, King, \& Segal, supra note at.

${ }^{57}$ For a summary of the incentives and disincetives in the constitutional and statutory contexts, see Table 3 , infra notes and accompanying text.

${ }^{58}$ U.S. CONST. ART. I, § 8.

${ }^{59}$ U.S. CONST. ART. II, $\S \S 1,2$.

60

${ }^{61}$ Hirabayshi v. United States, 320 U.S. 81 (1943); Youngstown Sheet \& Tube Co. v. Sawyer, 343 U.S. 579 (1952).
} 
noted that often extreme economic polices were necessary in times of war and the justices should not second-guess congressional strategies. In Burton's words, "In total war it is necessary that a civilian make sacrifices of his property and profits with at least the same fortitude as that with which a drafted soldier makes his traditional sacrifices of comfort, security, and life itself. . . . In war, both the raising and the support of the armed forces are essential and legitimate acts of Congress." ${ }^{26}$ Finally, Justice Jackson has argued that for the Court to interfere with the strategies of the elected branches of government during wartime is to interpret the Framers as having placed a higher priority on individual rights and interests than protecting the security and viability of the nation as a whole. This Jackson argued is akin to a "suicide pact" which cannot be what the Framer's had in mind when they created the Supreme Court as the third branch of government. ${ }^{63}$

Underlying this notion of deference and accommodation is the idea that the justices - like most Americans - have a strong preference for national security and that individual rights and interests must be sacrificed for the greater good. Moreover, because the Justices-like the Framers - seem to recognize that it is the elected officials of government who have the knowledge, the expertise, and the skill to make informed decisions on whether to go to war, how to fund the war, and, ultimately, how to win the war, their choices must be respected. The justices, experts in constitutional law and statutory interpretation, are not in a position to second-guess the wartime decisions and thus are able to maximize their own well-being - there safety and the safety of the nation - by stepping aside to allow the elected branches of government to do their job effectively. The incentive to defer and accommodate may exist at all times, but arguably will be particularly strong when the stakes are high, as in periods of major wars, and when a substantial number of personnel in the federal government are actively seeking to address the emergency at hand. ${ }^{64}$ In these periods, judicial interference arguably could exacerbate rather than ameliorate the crisis and thus deference is exceptionally important.

The specific form of judicial accommodation to Congress and the President, if it emerges at all, however, is not entirely clear. On the one hand, the justices may pursue a "strong form of deference" by issuing pro-government decisions in all the cases litigated irrespective of the nature of the claims or the types of parties involved. ${ }^{65}$ This general form of deference would help to assure the federal government creates uniform policy in times of crisis, rather than a fragmented approach to lawmaking that depends on the specific issue at hand. General deference would assure that the experts, the elected branches of government, have total control of policymaking in all areas of fiscal policy

\footnotetext{
62334 U.S. 742 (1948).

63 Terminiello v. Chicago, 337 U.S. 1, 37 (1949) (Jackson, J. dissenting).

${ }^{64}$ Courts adopting the accommodationist approach may do much more than merely decide in favor of the federal government in the cases on the docket, they may also adopt new standard and rules for reaching the pro-government outcomes. Once a wartime emergency has emerged, for example, the justices are free to adopt a "wartime standard of review," which may be quite a bit more deferential to the government than cases emerging during peacetime periods. This assures that the Court reaches a pro-government outcome but also gives clear instructions to lower federal courts to follow suit. In civil rights and liberties cases, the justices have indicated that this is precisely the approach that should be adopted. See Epstein, Ho, King, \& Segal, supra note at .

65 [Perhaps Clark discusses this?]
} 
during crisis periods. On the other hand, the Court may adopt a "weak form of deference," which would involve accommodation of the majoritarian bodies on issues that Congress and the President have explicitly and unambiguously addressed, but not deference generally or in every case involving the U.S. government that shows up on the docket. If deference emerges in this second, weak form, the Court will feel free to pursue its own preferences in times of crisis in the cases that raise issues to which neither Congress nor the President have not spoken. ${ }^{66}$

In the tax context, these different types of deference have very different implications for the government as a litigator in the Supreme Court. If the justices adopt the strong form - deference in all cases - then the government's win rate should increase in all the cases it litigates. But if the justices pursue the weak form of deference, then the government's chances of prevailing should depend on the types of law that Congress adopted to address the wartime emergency. As noted above, Congress did adopt very different strategies for funding wars over the course of the last century. In World War I, Congress primarily focused on corporate taxpayers for purposes of raising funds, whereas it financed World War II and the Korean War through a massive tax increase on both individual citizens and corporate entities but individuals shouldered the greatest portion of the wartime fiscal burden. ${ }^{67}$ The Vietnam and Gulf Wars ushered in fiscal policy changes that focused on individuals rather than corporations, but the new reforms were not as dramatic or speedy as those undertaken in the earlier wartime periods. ${ }^{68}$ Thus if the Court adopts a weak form of deference, government win rates are likely to change but only in cases that involve the type of taxpayer and they type of law addressed by Congress. Specifically, the government should have increased win rates in the WWI corporate cases; in the WWII individual tax cases; and the Korean War individual tax cases. But the Vietnam and Gulf Wars should have no any impact whatsoever on the Court.

A second incentive the justices have for deferring to Congress and the President involves a desire to avoid institutional sanctions, irrespective of the justices' views of the Court's authority and expertise to contribute to wartime policymaking. When the Court fails to accommodate the elected branches of government, the justices risk a range of negative responses to its decisions. ${ }^{69}$ Put differently, even if the Court believed it could usefully contribute to wartime policymaking by undermining and overturning the policies adopted by Congress and the President, the justices may hesitate to involve themselves out of fear of punishment. In the statutory context, as noted above, Congress is free to override the Court with new legislation and these overrides are likely to come quickly and clearly, thereby undercutting the Court's position as a legitimate contributor to

\footnotetext{
${ }^{66}$ One team of authors has argued that deference could also come in a third form: deference in cases addressing issues that have not been addressed by Congress or the President but no deference in cases that raise questions considered by the elected branch of government. See Epstein, Ho, King, \& Segal, supra note at. Because it is difficult to identify a theory that could motivate this type of deference, I set it aside for purposes of this discussion.

${ }^{67}$ See supra notes and accompanying text.

${ }^{68}$ See supra notes and accompanying text.

${ }^{69}$ EPSTEIN \& KNIGHT, supra note at.
} 
wartime policy. Although Congress does not have this recourse in constitutional cases, it is able to retaliate by eliminating the Court's jurisdiction to hear classes of cases or, more dramatically, by attempting to impeach the individual justices themselves in the face of undesired judicial outcomes but these sanctions may take more time and energy to implement than those available in the statutory context. Thus while positive political theorists have noted that negative congressional responses to Court opinions make it more difficult for the Court to achieve its short-term policy or jurisprudential goals and would erode the judiciary's legitimacy in the long run, they may be quite a bit more effective in statutory contexts. ${ }^{70}$

One final incentive that the justices have for ruling in favor the federal government during wartime is not grounded in concerns for wartime expertise or institutional factors - or even in rational decision-making - but in individual feelings that emerge when the nation is at risk. A large number of studies have found that when the nation is under siege from a perceived international threat, citizens rally around the flag and offer increased support for the President. ${ }^{71}$ This "rally effect" enables the President (and Congress) to pursue policies and programs that may not be feasible in peacetime but are adopted with support by the populace in crisis situations. Justices, like Americans generally, may experience nationalistic feelings and be more sympathetic to the government's legal positions especially in cases and controversies that impact war activities. ${ }^{72}$ Rally effects are generally short-lived and do not persist throughout the entire wartime periods. Thus, if it is the rally effect, and not the actual war, that effectuates changes in judicial decision-making, then we should observe a progovernment bias while the rally lasts but no longer.

Before turning to the disincentives to defer to Congress and the President, it is worthwhile to note that the judicial concerns regarding their own military expertise and the behavioral swings that come with a rally effect are specific to wartime eras. Thus these incentives to defer unambiguously imply differences in wartime and peacetime government win-rates. The incentives to defer that are associated with sanctions, however, exist in both peacetime and wartime and thus cannot help explain the difference in judicial decision-making during the two different periods. Accordingly, I will focus on the mechanisms associated with expertise (general and specific deference) and the rally effect in the empirical section of this paper.

Turning now from incentives to disincentives to accommodate Congress and the President. The justices have at least two disincentives to defer. The judicial desire to constrain the federal government in times of war rather than enable it is likely to emerge from the fact that many legal scholars - as well as the justices themselves - believe the Supreme Court represents the third branch of government, the independent branch, and one that the Framers designed to operate above the fray of politics. ${ }^{13}$ Through a system

\footnotetext{
${ }^{70}$ EPSTEIN \& KNIGHT, supra note at.

${ }^{71}$ [Cite Surveys, Political Science literature on war]

${ }_{73}^{72}$ Grossman.

73
} 
of life-tenure and financial security, the justices (unlike elected politicians) are able to reach rational and balanced decisions that work to protect minority members of the community from unfair policies that are so apt to emerge from majoritarian bodies. Many justices have suggested that they must take their "guarantor role" seriously and thus give legislative acts that implicate individual rights and interests heightened scrutiny. In fact, various justices have suggested that this role exists in all eras, but is particularly important in times of war when legislative policies become more extreme and possibly violative of individual interests in the name of the greater social good. ${ }^{74}$

Not only do the justices have an incentive to constrain the federal government when dramatic new legislation emerges that harms minority interests (whether rights, liberties, or property interests), but failing to guard against this threat could be costly in terms of legitimacy. ${ }^{75}$ Put differently, even if the justices prefer to accommodate the government in times of crisis (because they agree with the law or due to the perceived inequalities in expertise), to do so could lead to the popular belief that the Court itself is simply a third majoritarian body and not an independent branch of government entitled to respect and deference. This lack of legitimacy, in turn, could lead individuals, entities, and even government actors to ignore or even defy the Court's rulings given that the Court is acting like a majoritarian body but was not elected in a democratic process. ${ }^{76}$ Decisions that go against the government in times of war, therefore, can operate to cultivate the Court's status as an independent branch of government, a status that the justices are likely to seek to protect and cultivate their unique position in our system of separated powers.

These incentives to constrain are heightened in times of war and thus offer explanatory value for understanding differences in judicial decision-making, but they are unique to constitutional cases. This is because the "guarantor role" emerges from the individual rights and liberties found in the Constitution and it is the Court that has the responsibility for determining when and if Congress has violated these rights and liberties. If the litigant fails to raise a constitutional claim, then as noted above, the justices' task is not to protect minority interests but to implement legislative preferences even they very much favor the majority over the individual. Thus, while it is true that the legislators do pursue dramatic fiscal policy changes in wartime that may have harmful effects on individual property rights, without a constitutional question at hand, the justices' will simply defer to the wording of the law and the intent of Congress.

Table 3 summarizes the incentives and disincentives identified above and identifies when they are likely to emerge. First, recall that the extant literature has considered judicial incentives only in the constitutional context, but note that these

${ }^{76}$ Scholars and commentators that subscribe to the containment have also noted that the Court not only acts as a protector of rights, but also as a "republican schoolmaster" that educates the public and its leaders about important aspects of rights and liberties and to dispose of this role in periods of national emergencies to undermine the Court's role as an independent branch of government. See, e.g., SiLVERSTEIN, supra note at; Lerner, supra note at. 
incentives differ quite a bit from those found in the statutory context. Specifically, in the constitutional context, the Court has disincentives to accommodate the federal government but no such disincentives exist in the statutory context. Second, notice that the desire to avoid sanctions exists in both peacetime and wartime, and thus offers no explanatory value for understanding the differences in judicial decision-making in wartime versus peacetime.

Table 3: Unpacking Judicial Incentives in Wartime and Peacetime

\begin{tabular}{|c|c|c|c|c|c|}
\hline & \multirow{2}{*}{ Judicial Incentives } & \multicolumn{2}{|c|}{$\begin{array}{l}\text { Statutory } \\
\text { Cases }\end{array}$} & \multicolumn{2}{|c|}{$\begin{array}{l}\text { Constitutional } \\
\text { Cases }\end{array}$} \\
\hline & & War & Peace & War & Peace \\
\hline \multicolumn{6}{|c|}{ Pro-Government Incentives: } \\
\hline 1) & $\begin{array}{l}\text { Support national security through complete } \\
\text { deference to majoritarian bodies }\end{array}$ & Yes & No & Yes & No \\
\hline 2) & $\begin{array}{l}\text { Support national security through limited } \\
\text { deference to majoritarian bodies }\end{array}$ & Yes & No & Yes & No \\
\hline 3) & Avoid sanctions & $\mathrm{Yg}_{\mathrm{g}}$ & & & \\
\hline 4) & Rally effect & Yes & No & Yes & No \\
\hline \multicolumn{6}{|c|}{ Anti-Government Incentives: } \\
\hline 1) & $\begin{array}{l}\text { Cultivate status as independent body } \\
\text { above the fray of politics }\end{array}$ & & & & \\
\hline 2) & $\begin{array}{l}\text { Protect minorities from unfair majoritarian } \\
\text { decision-making }\end{array}$ & Xo & Xo & & \\
\hline
\end{tabular}

*Note: Incentives that are identical in peacetime and wartime (which have a line drawn through them) cannot explain differences in observed outcomes in the different periods. This study will focus on the possible explanations for observed differences in the statutory context.

In the statutory context, the only mechanisms that can lead the justices to issue more pro-government decisions in times of crisis are: 1) the desire to support national security through complete deference to the majoritarian branches of government, 2) the desire to support national security through limited deference to majoritarion bodies on issues specifically addressed by Congress and the President, and 3) the rally effect. From Table 3 we can also conclude that these same mechanisms operate in the constitutional context, but the justices also have strong incentives to issue anti-government decisions. Thus we cannot predict the precise affect of war on judicial decision-making outside the context of statutory decision-making. For this reason, and because the number of constitutional cases in the database are so few, I focus on statutory decision-making in my quantitative investigation immediately below. 


\section{The Effects of War on Supreme Court Fiscal Decision-Making}

I now turn to an empirical investigation of the effects of war on judicial fiscal policy. Recall Section II investigated the raw data and found evidence that war induced substantial changes in judicial behavior in the tax context. Section III explored possible explanations for these differences and identified three possible mechanisms that could explain the observed judicial behavior. I now re-examine the data to determine whether the findings identified in Section II are robust to various statistical controls. I also seek to identify the best possible explanation for this change in behavior, if it continues to exist in the face of other possible explanatory factors. Section IVA describes three simple models and outlines my predictions; Section IVB discusses my assumptions and the possible biases of my study; and Section IVC presents empirical results. I find that the justices do exhibit pro-government preferences in times of war, and that the most likely explanation for the observed results is a desire to support national security through limited deference to the majoritarian bodies. I do not find support for general deference or for the rally effect as explanations for judicial decision-making in crisis periods. Finally, the data indicate the desire to support a strong and uniform national policy through limited deference was strongest during the WWII era.

\section{A. Models and Predictions.}

For purposes of this paper, I focus on the statutory decisions in the database and set aside the Court's opinions in the constitutional cases. As noted above, I do this for several reasons. First, the number of constitutional decisions in the database is few, just $14 \%$ of all cases involved a constitutional claim $(n=156)$. Second, in every single war, except the Vietnam War, the U.S. government prevailed in $100 \%$ of the cases it litigated. This means that the dataset does not provide enough variation for purposes of statistical analysis. ${ }^{77}$ Third, the incentive structure outlined above does not offer the clear

\footnotetext{
77 The trends in constitutional decision-making are summarized in Table 1A below.
}

Table 1A: Trends in Constitutional Tax Cases

\begin{tabular}{lcc}
\hline \hline \multicolumn{1}{c}{ Government Prevails } & Wartime & Peacetime \\
\hline \hline Constitutional Cases Generally $N=156$ & $76 \%$ & $86 \%$ \\
WWI, $N=1$ & $100 \%$ & \\
WWII, $N=11$ & $100 \%$ & \\
Korean War $N=2$ & $100 \%$ & \\
Vietnam $N=7$ & $29 \%$ & \\
\hline \hline
\end{tabular}

Although the Court primarily focuses on statutory controversies in both wartime and peacetime, it granted certiorari to and decided 156 cases raising constitutional questions between 1909 and 2005. Only 21 of these cases, however, were decided during wartime and in every war, with the exception of the Vietnam War, the Court decided $100 \%$ of the cases in favor the government. While the number of constitutional cases that reached the Supreme Court is very small, this change that occurred in the Vietnam era suggests an abrupt judicial change of viewpoint. Although the types of cases that emerged on the Court's docket did not notable change, the Court's median ideology changes quite a bit by the Vietnam War era. The Court's average median ideology during the Vietnam was -.6884, which is quite a bit more liberal than the Courts that decided the constitutional cases in WWII, which had a score equal to -.2748 and the Korean War, 
predictions in constitutional cases as it does in statutory cases and thus it will be impossible to identify the specific mechanisms at work. And finally, the extant literature has thoroughly investigated Supreme Court constitutional decision-making in times of war and I seek to extend this literature into the statutory context for purposes of understanding its generalizability.

Judicial choices in the statutory context are likely to be grounded in several factors, but for purposes of this paper I am interested only in the effects of war. Because my dependent variable is binary, I adopt a probit model, which provides the most advantages for analyzing this type of data. Specifically, I seek to understand and explain whether war changes the probability that the government will prevail in wartime tax cases relative to similar cases litigated in peacetime. My model can be summarized as follows:

$$
\operatorname{Pr}\left(Y_{i j}=1\right)=\Phi\left(\beta_{0}+\beta_{1} I(w a r=1)+\beta \mathbf{X}_{i}\right)
$$

Where $Y$ is Court decision in statutory case $i$ that goes in favor of either the taxpayer or government during war $j$; war is an indicator variable for the existence of on-going major military activity; $\boldsymbol{X}$ is a vector of independent variables that I will discuss further below. My coefficient of interest is on the war variable, $\beta_{1}$, and if the Court desires to promote national security in times of war through a generalized approach to deference, I expect that this coefficient will be positive and statistically significant. That is to say, the existence of war will increase the probability that the U.S. government will prevail in tax cases generally.

Recall from Section III, however, that there are two other possible mechanisms that can work as mechanisms producing an increased number of pro-government decisions in times of war. If the justices desire to promote national security, but only on issues that Congress and the President specifically address, then we should not observe an overall pro-government bias in times of war but only a bias in cases that involve taxpayers and laws specifically addressed by Congress and the President. As noted above, Congress acted swiftly and dramatically in WWI, WWII, and the Korean War to raise taxes to extreme levels. During the Vietnam and Gulf Wars, tax rates increased but the reforms were minor and historians argue they were not directly related to war funding concerns. In order examine the possibility of a weak form of deference rather than a strong form, I rerun the model above but add a separate indicator variable for each major war:

$$
\begin{aligned}
& \operatorname{Pr}\left(Y_{i j}=1\right)=\Phi\left(\beta_{0}+\beta_{1} I(W W=1)+\beta_{2} I(W W I I=1)+\beta_{3}(\text { Korea })\right. \\
& \left.+\beta_{4} I(\text { Vietnam }=1)+\beta_{5} I(\text { Gulf }=1)+\beta \mathbf{X}_{i}\right)
\end{aligned}
$$

which had an average score of .3969. Thus from the political changes alone, we might expect the Court to change its views. Yet no study or theory suggests that liberal courts will favor taxpayers over the government - the theory suggests just the opposite. 
Where $Y$ is Court decision in statutory case $i$ that goes in favor of either the taxpayer or government in war $j$; WWI, WWII, Korea, Vietnam, and Gulf are all indicator variables for the named war; and $\boldsymbol{X}$ is a vector of independent variables. My coefficients of interest again are those attached to the war variables, $\beta_{1}$ through $\beta_{5}$. If the justices have a general preference for uniform government policies in times of war, then all six of these coefficients will be positive and statistically significant. If the justices adhere to weak form of deference then I expect on the coefficients on WWI, WWII, and the Korean War, $\beta_{1}, \beta_{2}$, and $\beta_{3}$, to be positive and statistically significant but the coefficients on the Vietnam and Gulf Wars, $\beta_{4}$ and $\beta_{5}$, to be $=0$.

To further investigate the possibility of a weak form of deference, I examine the corporate and taxpayers cases separately. This will enable me to identify whether the justices treat these taxpayers differently depending on the wartime era under consideration. Recall that Congress focused on corporations as the means to raise large amounts of revenue very quickly in WWI, but in WWII and the Korean War, legislators looked to individual taxpayers for purposes of raising revenue. Given that we observe unique legislative changes in each wartime period, I expect that judicial choices will also reflect these congressional choices if the justices have adopted a weak form of deference.

To investigate this possibility, I rerun the model immediately above first with only corporate taxpayers and then with only individual taxpayers. My coefficients of interest continue to be those associated with the five wars, $\beta_{1}$ through $\beta_{5}$. In WWI, when Congress quickly and significantly increased the tax obligations of corporations, the data and theory above lead me to predict that $\beta_{1}$ will be positive - indicating that the Court is more likely to side with the government in corporate cases than in individual cases. In all other wars, I do not expect war to play a role as corporations were not the major source of revenue and thus I expect $\beta_{2}$, though $\beta_{5}=0$. With respect to individual taxpayer cases, I expect the opposite. That is, I expect the coefficient on WWI, $\beta_{1}$, will be negative as Congress did not rely on individuals in WWI, but $\beta_{2}$ and $\beta_{3}$ to be positive as Congress relied on individuals in WWII and the Korean War as a funding source. Finally, I expect the coefficients on the Vietnam and Gulf Wars, $\beta_{4}$ and $\beta_{5}$, to be $=0$ as Congress did not heavily rely on taxpayers at all to fund the wars.

Finally, I investigate the possibility that changes in judicial decision-making are entirely associated with the rally effect and not war at all. For purposes of partialling out these effects, I fit the following model:

$$
\operatorname{Pr}\left(Y_{i j}=1\right)=\Phi\left(\beta_{0}+\beta_{1} I(\text { rally }=1)+\beta \mathbf{X}_{i}\right)
$$

Where $Y$ is Court decision in statutory case $i$ that goes in favor of either the taxpayer or government during war $j$; rally is a variable that controls for a spike in Presidential popularity rankings; $\boldsymbol{X}$ is a vector of independent variables. My coefficient of interest is on the rally variable, $\beta_{1}$. If the Court is affected by the pro-American feelings due to the perceived national threat but not by concerns associated with military expertise, we should observe this coefficient to be positive and statistically significant. That is to say, 
the existence of the rally and not war increases the probability that the U.S. government will prevail in tax cases generally.

\section{B. $\quad$ Assumptions and Possible Selection Biases}

For purposes of understanding the assumptions that underlie this study and the possible biases that might emerge, it is useful to conceptualize the variable "war" as if it were a "treatment" on the Supreme Court justices. Placed into this context, it is easy to see that this study seeks to measure the effects of treatment (i.e. war) on judicial tax decisions. Just as countless medical studies seek to understand and explain whether a new drug - the treatment - affects the outcome of a patient, I seek to understand and explain whether war affects the outcome of tax cases in the Supreme Court. As noted above, economists label this type of study a "natural experiment" because the treatment arose due to an exogenous event (in this context, Congress and the President made the decision to go to war). ${ }^{78}$ A natural experiment or quasi-experiment always has a control group, which is not affected by the policy change, and a treatment group, which we believe is affected by the policy change. The behaviors or outcomes of the two groups are then compared for purposes of measuring the affects of the treatment on the population of interest. ${ }^{79}$ Because the U.S. engaged in five major wars over the course of the Twentieth Century, we can think of my study as a series of five natural experiments on the Court, each one correlating with a different war.

To understand the assumptions underlying this study and possible hidden biases, consider the counterfactual framework that motivates any experiment. Denote $y_{1}$ as the outcome with treatment and $y_{0}$ as the outcome without treatment. ${ }^{80}$ To measure the true effects of treatment, I would like to identify the average difference in the outcomes with and without treatment, $y_{1}-y_{0}$ or, put differently, the quantity of interest is the average treatment effect which can be denoted: $A T E \equiv \mathrm{E}\left(y_{1}-y_{0}\right) .{ }^{81} A T E$ is the expected effect of treatment on a randomly drawn person from the population. In my context, $A T E$ would be the expected effect of war on a randomly drawn case between the period 1909 and 2000. The problem, of course, is that a case cannot be in both states (i.e. the exact same case cannot be litigated in both wartime and peacetime) and thus we cannot observe both $y_{1}$ and $y_{0}{ }^{82}$ Empiricists label this difficulty the Fundamental Problem of Causal Inference and have developed techniques to overcome the dilemma. ${ }^{83}$ One possibility is randomly to divide cases into a treatment group (the war cases) and a control group (the peacetime cases). With randomization, there is no reason to believe that in the absence of treatment

${ }^{80}$ JeFFrey M. WoOldRidge, ECONOMETRIC ANALYSis OF Cross SeCtion AND PANEl DATA 603-609 (2002).

${ }^{81} \mathrm{Id}$.

${ }^{82} \mathrm{Id}$

${ }^{83}$ See Judea Pearl, Causality: Models, Reasoning, AND Inference (2000); Donald Rubin, Estimating Causal Effects of Treatments in Randomized and NonRandomized Studies, 66 J. ED. PsYCH. 689 (1974); Paul Holland, Statistics and Causal Inference, 81 J. AM. STAT. Assoc. 946 (1986). 
the two groups would be, on average, different from one another. Thus the outcome of the control group would provide a valid "counterfactual" for the treatment group.

The central feature of a classic randomized experiment - the existence of a control group to estimate what would have happened in the absence of the treatmentlies behind the idea of a natural experiment, which is what this study relies upon to identify the effects of war. In the natural experiment, the researcher must make use of the differences in outcomes between the treatment group and a control group, just as in a classic experiment, but the treatment status emerged through nature or, in this study, through the decision-making process of Congress and the President. ${ }^{84}$ The fact that the treatment status in this study was not determined by a randomized procedure, however, raises the possibility that any comparisons between the two groups of cases will be biased. In order to determine the credibility of the natural experiment - to assure unbiased results - it is important to examine the characteristics of the cases that were placed into the control and treatment groups due to the foreign policy crisis that emerged. Valid causal inference requires that the treatment and control groups be identical on all relevant factors. ${ }^{85}$ If the two groups differ, then it is possible that the observed differences in judicial outcomes has nothing to do with the war and everything to do with the type of case litigated in Court or the judicial make-up of the Court. ${ }^{86}$

For these purposes, recall the summary statistics presented in Table 1 comparing the two groups of cases. Table 1 indicates that the control and treatment groups (that is, the peacetime and wartime cases, respectively) are nearly identical on ten of the thirteen factors observed. Thus as noted above, the cases in both periods have similar types of claims, parties, interpretive approaches, reasons for granting certiorari, case complexity, media coverage and so forth. These statistics offer some evidence for the credibility of this natural experiment for assessing the effects of war.

The one observable difference between the wartime and peacetime cases that could confound the result of this study is the ideology of the Court. Table 1 indicates that the justices are liberal in both eras, but are quite a bit more liberal in times of war. ${ }^{87}$ This fact poses a problem for this study as many scholars have theorized that liberal justices are more likely to side with the government than the taxpayer in tax cases. Numerous empirical studies investigating this theory exist, but only one study found a correlation between judicial ideology and tax outcomes - and the finding is limited to cases involving corporate entities. ${ }^{88}$ Thus if we find that wartime Courts produce an increased number of pro-government decisions in the corporate context, this finding may not be due to the incentive structure discussed above but to the ideology of the Court. Because no scholar has ever identified a correlation between judicial ideology and pro-government

\footnotetext{
${ }^{84}$ David Card \& Alan B. Krueger, Myth and Measurement: The New Economics of the MINIMUM WAGE 20-28 (1995)

85

86

${ }^{87}$ See supra notes and accompanying text.

${ }^{88}$ SeE Nancy Staudt, Lee Epstein, \& Peter Weidenbeck, The Ideological Component of Taxation, WASH. U. L. REV. (2007)
} 
outcomes in individual taxpayer cases, notwithstanding a number of attempts, ideology should is not a worrisome confounding factor outside the corporate context. For this reason, and various other reasons discussed above associated with the type of legal reform Congress adopted, I examine the cases in the aggregate and then separately based on whether the taxpayer is a corporation or individual.

There is one final - and unobservable - feature of the two groups of cases that may also confound the empirical results. The data presented in Table 1 does not provide a comparison of the cases based on the taxpayers' probability of prevailing. This is an important dimension because if the taxpayers litigate a larger number of cases in which they are likely to lose in wartime relative to peacetime, cases in which the law unambiguously goes in favor of the government, then the justices will decide a greater percentage of the cases in favor of the government even if their choice calculus has not changed at all. In short, if the dataset suffers from this selection problem (i.e. difference selection of cases exist in wartime than peacetime), then we may observe a positive "war effect" and attribute this effect to judicial behavioral changes when in fact the outcomes have everything to do with the taxpayers and nothing to do with the justices themselves.

Why would the taxpayers litigate easy cases in times of war versus peacetime? One explanation has to do with the law itself: As Congress raises tax rates and imposes increased burdens on taxpayers - taxpayers are likely to bring more and more challenges to the law. After all, even if the probability of prevailing is quite low, if the stakes are high, then taxpayers will have an increased incentive to challenge the IRS in federal court. $^{89}$

The data, however, suggest taxpayers have not adopted this strategy. First, the Court granted certiorari to nearly all the cases decided during wartime prior to the time that military actions began and prior to the time that Congress adopted the legal reforms that are likely to change the taxpayers' calculus for deciding whether or not to litigate. The time period from the initial filing in lower federal court to the certiorari decision is roughly seven years for the cases in the database, and thus taxpayers subjected to heavy wartime taxes cannot expect to get a hearing until well after the wartime endeavors have ceased. In fact, the only war that lasted long enough to allow early legislation to reach the Supreme Court before the end of the war is the Vietnam War-but Congress did not adopt any wartime legislation until 1969 only five years before the war's conclusion. ${ }^{90}$ Second, the data presented in Table 1 indicate that that the percentage of cases considered by the Supreme Court in which the taxpayer prevailed in the lower courts is nearly identical in peacetime and wartime, $53 \%$ and $55 \%$ respectively. ${ }^{91}$ These percentages suggest that the justices were not granting a disproportionate number of easy cases in

\footnotetext{
${ }^{89}$ Steven Shavell, Any Frequency of Plaintiff Victory at Trial is Possible, 25 J. LeGAL STUD. 493-501 (1996).

${ }^{90}$ If taxpayers are litigating cases that are easier for the government to win but these cases are not decided until after the war, then the effect will be to bias the estimate of the war effects downward to 0 . That is to say, these cases, if they exist, will lead to many more pro-government outcomes in times of peace and thus the comparison between peacetime and wartime decision-making will be curbed.

${ }^{91}$ See supra notes and accompanying text.
} 
wartime, if they were, the proportion of cases in which the taxpayer won should notably decrease in wartime. From this data, we can conclude that the study does not suffer from a selection effect with respect to the type of taxpayers that come into Court in different eras.

In sum, the evidence suggests that I have a credible natural experiment with one possible confounding factor: ideology in cases involving corporate taxpayer cases. It may be impossible to separate the effects of war from ideology in this context and thus I pay special attention to this problem when presenting my findings.

\section{Empirical Results.}

I now present the empirical results from the models above. My variable of interest is war and its coefficient measures the change in the probability of progovernment decision in wartime versus peacetime. I estimate my models first with war generally, then with war disaggregated into the five major wars in the database, namely WWI, WWII, the Korean War, the Vietnam War, and the Gulf War. I then examine just how robust the simple models are to models that include a number of covariates that might also have explanatory value for explaining judicial decision-making. Because my dependent variable in each model is the case outcome and this is a binary variable coded $=1$ if the government wins and coded $=0$ if the taxpayer wins, I adopt a probit model. ${ }^{93}$ The raw coefficients in probit models, unlike OLS models, are difficult to interpret and thus I do not present the raw coefficients but rather I present coefficients that identify the actual change in the predicted probability of a pro-government. This means that the coefficients presented in each of the tables below are directly interpretable in the same manner as an OLS model. Put even more directly, the coefficients indicate the percentage point change in the probability of a pro-government decision with a unit increase in the independent variable; the coefficient on war, therefore, identifies the percentage increase in the likelihood of a pro-government decision during wartime versus peacetime. ${ }^{94}$ The variables that achieve statistical significance, an indication that we can have confidence in the estimates, are marked with $* * *$ if we can trust the coefficient with $99 \%$ confidence and with ** if we can trust the coefficient with $95 \%$ confidence.

Table 4 presents four different models assessing the effects of war on judicial decision-making. The first model examines case outcomes only as a function of war and indicates that the existence of war increases the probability that the government will prevail in tax cases by 7 percentage points. The average government win rate in the model is $69 \%$, and from Table 5 we can now conclude that this probability increases to

\footnotetext{
${ }^{93}$ For a discussion of models for binary dependent variables, see J. SCOTT LONG, REGRESSION MODELS FOR CATEGORICAL AND LIMITED DEPENDENT VARIABLES (1997).

${ }^{94}$ Specifically, the coefficients can be interpreted in the following way: For a one unit increase in the independent variable, the predicted probability of a pro-government decision increases (decreases) by the percentage points indicated by the coefficient. See LONG, supra note at 75. Or more formally, $\Delta \operatorname{Pr}(y=1 \mid \mathbf{x})$ $/ \Delta x_{\mathrm{k}}=\operatorname{Pr}\left(y=1 \mid \mathbf{x}, x_{\mathrm{k}}+\delta\right)-\operatorname{Pr}\left(y=1 \mid \mathbf{x}, x_{\mathrm{k}}\right)$. See id.
} 
$76 \%$ during wartime. Model 2 disaggregates the wartime periods and suggests that war has not affected the Supreme Court in every era in the identical way; instead, this model indicates that WWII is driving all the results presented in Column 1. The government's likelihood of winning in WWII was 9 percentage points higher than in peacetime and this finding is statistically significant. The coefficient on WWI is negative, indicating the government is less likely to prevail in this era but this finding is not statistically significant. The coefficient on the Vietnam and Gulf wars are positive but also not statistically significant indicating that we cannot be confident war has any impact whatsoever on the Supreme Court during these time periods. Notably, these results do not change depending on whether I include or exclude the corporate taxpayers. This suggests that ideology is not confounding the results - a concern discussed above.

Models 3 and 4 refit the data adding six covariates to test the robustness of the results in presented in the first two models. Adding controls for the existence of an economic crisis, the party litigating the case, the Court's interpretive method, and the complexity of the case does not have any effect on the results presented in the simple models. I still find a statistically significant result for war in the aggregate as well as for WWII in model 4.

Table 4: General War Effects in Statutory Cases

\begin{tabular}{lcccl}
\hline \multicolumn{5}{c}{ Probit Models With Marginal Effects } \\
\hline \hline Independent Variable & $(1)$ & $(2)$ & $(3)$ & $(4)$ \\
& & & & \\
\hline War & $.07(.033)^{* *}$ & & $.08(.03)^{* * *}$ & \\
World War I & & $-.06(.11)$ & & $-.10(.12)$ \\
World War II & $.09(.03)^{* *}$ & & $.089(.04)^{* *}$ \\
Korean War & $.03(.09)$ & & $.038(.09)$ \\
Vietnam War & $.07(.06)$ & & $.10(.06)$ \\
Economic Crisis & & & $.08(.03)^{* *}$ & $.079(.03)^{* * *}$ \\
Corporate Taxpayer & & & $-.05(.03)$ & $-.054(.03)$ \\
Individual Taxpayer & & & $-.01(.04)$ & $-.003(.04)$ \\
Textualist Method & & & $.01(.03)$ & $.009(.03)$ \\
Substantive method & & & $-.05(.03)^{*}$ & $-.06(.028)$ \\
Complex Case & & & $.12(.05)^{* *}$ & $.134(.05)^{* *}$ \\
\hline Observations & 943 & 943 & 942 & 942 \\
\hline Pseudo R ${ }^{2}$ & .005 & .008 & .01 & .02 \\
\hline \hline
\end{tabular}

* Note: Dependent variable is case outcome coded $=1$ if the government prevails and coded $=0$ if the taxpayer prevails. All the independent variables are binary; the models present robust standard errors. Variables marked with *** indicates statistical significance at $\mathrm{p} \leq .01$ level and $* *$ at the $\mathrm{p} \leq .05$.

In order to determine whether the results presented in Table 4 are due to a general or weak form of deference, I re-examine the models separately for individual and corporate taxpayers. To do this, I take the same approach as in Table 4: I first examine simple models and then move to progressively more complex models that control for various factors that might confound the results. Table 5 presents the empirical findings for the corporate taxpayers and Table 6 presents results for individual taxpayers. 
Beginning first with the corporate taxpayer cases. The data present surprising results - there is no war affect either in the aggregate or with respect to individual wartime periods. These results hold in the both the simple models (models 1 and 2) and the more complex models (models 3 and 4). In fact, the only factors that impact the government's probability of prevailing in the tax cases are national economic crises and the complexity of the case-when these two variables are both present the U.S. government's probability of winning is close to $100 \%$ ! The fact that war does not have any explanatory value in corporate taxpayer cases - even controlling for Court ideology - suggests something important about the mechanisms for wartime judicial behavior. If the incentive associated with creating national security through general deference to the U.S. government accurately described the Court, then we should have observed a positive and statistically significant coefficient on war in every one of these models, a finding we do not have.

Because the findings on not statistically significant we have proof that the Court does not adopt a position of generalized deference; we have now eliminated one possible explanation for the observed data. But do the results suggest selective deference? The only period in which Congress looked to corporate taxpayers to fund the wartime activities was in WWI and thus we should have observed a positive coefficient on WWI - and model 2 in Table 5 indicates as much. The coefficient indicates that during WWI, the government was 13 percentage points more likely to prevail than in peacetime - a large substantive effect. This finding as just noted, however, is not statistically significant and thus we cannot be confident of the results. Unfortunately, this lack of statistical significance may be due to the fact that WWI involved only 10 corporate cases and thus statistical power is very is limited. If we look back to the raw data presented above in Table 2, we can see that the government won $80 \%$ of the controversies and this provides limited evidence that selective deference is the best explanation for the observed judicial outcomes in times of war. Finally, it is valuable to note, that if the justices indeed adopted a weak form of deference, then we should not observe any effect in WWII, and the Korean, Vietnam, and Gulf War and the models in Table 5 confirm this result. 
Table 5: War Effects in Corporate Taxpayer Cases

\begin{tabular}{|c|c|c|c|c|}
\hline \multicolumn{5}{|c|}{ " Probit Models With Marginal Effects } \\
\hline Independent Variable & (1) & (2) & (3) & (4) \\
\hline War & $.08(.05)$ & & $-.04(.08)$ & \\
\hline World War I & & $.13(.14)$ & & \\
\hline World War II & & $.007(.06)$ & & $-.09(.08)$ \\
\hline Korean War & & $-.30(.27)$ & & $-.15(.31)$ \\
\hline Vietnam War & & $.12(.10)$ & & $.04(.13)$ \\
\hline Economic Crisis & & & $-.11(.26)$ & $.08(.075)^{* *}$ \\
\hline Textualist Method & & & $.05(.06)$ & $.06(.06)$ \\
\hline Substantive method & & & $-.04(.07)$ & $-.03(.07)$ \\
\hline Complex Case & & & $.41(.17)^{* *}$ & $.43(.17)^{* * *}$ \\
\hline Court Politics & & & $-.15(.11)$ & $-.18(.12)$ \\
\hline Observations & 383 & 383 & 201 & 201 \\
\hline Pseudo $\mathrm{R}^{2}$ & .002 & .01 & .04 & .05 \\
\hline
\end{tabular}

* Note: Dependent variable is case outcome coded $=1$ if the government prevails and coded $=0$ if the taxpayer prevails. All the independent variables are binary; the models present robust standard errors. Variables marked with *** indicates statistical significance at $\mathrm{p} \leq .01$ level and $* *$ at the $\mathrm{p} \leq .05$.

Table 6 presents the empirical findings with respect to individual taxpayers. Regardless of how the models are specified, war has an impact on WWI and WWII cases, but not in the later wartime periods. Notably the findings go in different directions in each of these two wars: In WWI, the government is $37 \%$ less likely to win an individual tax case and in WWII, the government is $23 \%$ more like to win an case involving an individual taxpayer. Given that Congress did not rely on individual taxpayers in WWI but relied heavily on this group in WWII for purposes of funding the wars, we view Table 6, along with Table 5, as confirming the idea that the Court adopts a specific form of deference. We do not observe generalized deference to all cases, but only to cases that involve taxpayers specifically addressed by Congress in the wartime legislation. ${ }^{95}$

\footnotetext{
95 These results also hold when I examine each war separately and compare the government win-rates in individual versus corporate taxpayer cases. Table $2 \mathrm{~A}$ presents the results of these regressions and confirm the findings in the text.
}

Table 5A: Corporate versus Individual Taxpayers

\begin{tabular}{|c|c|c|c|c|}
\hline \multicolumn{5}{|c|}{ Probit Models with Marginal Effects } \\
\hline Independent Variable & $\begin{array}{c}\text { World War I } \\
\mathrm{n}=14\end{array}$ & $\begin{array}{c}\text { World War II } \\
n=172\end{array}$ & $\begin{array}{c}\text { Korean War } \\
\mathrm{n}=28\end{array}$ & $\begin{array}{c}\text { Vietnam War } \\
n=52\end{array}$ \\
\hline $\begin{array}{l}\text { Corporate Taxpayer } \\
\text { Textualist Method } \\
\text { Substantive Method } \\
\text { Court Politics } \\
\mathrm{R}^{2}\end{array}$ & $\begin{array}{l}.52 * *(.260) \\
-.20(.24)\end{array}$ & $\begin{array}{l}-.19 * *(.07) \\
-.08(.081) \\
-.10(.079) \\
-.15(.11) \\
.096\end{array}$ & $\begin{array}{l}.11(.44) \\
.5(.22) \\
-.56(.30) \\
-.29(.25) \\
.203\end{array}$ & $\begin{array}{l}.001(.14) \\
.039(.15) \\
.07(.17) \\
-.22(.19) \\
.039\end{array}$ \\
\hline
\end{tabular}


Table 4: War Effects in Individual Taxpayer Cases

\begin{tabular}{|c|c|c|c|c|c|}
\hline \multicolumn{6}{|c|}{ "Probit Model With Marginal Effects } \\
\hline Independent Variable & $(1)$ & $(2)$ & (3) & (4) & $(5)$ \\
\hline War & $.14(.05)^{* *}$ & & $.09(.07)$ & & \\
\hline World War I & & $-.37(.18)^{*}$ & & $-.37(.18)^{* *}$ & \\
\hline World War II & & $.23(.07)^{* * *}$ & & $.23(.05)^{* * *}$ & $.16(.07)^{* *}$ \\
\hline Korean War & & $.02(.13)$ & & $-.05(.14)$ & $.04(.12)$ \\
\hline Vietnam War & & $.11(.10)$ & & $.11(.10)$ & $-.02(.12)$ \\
\hline Economic Crisis & & & $.004(.17)$ & $-.19(.10)$ & $-.10(.22)$ \\
\hline Textualist Method & & & $.02(.06)$ & $-.09(.06)$ & $.02(.06)$ \\
\hline Substantive method & & & $.05(.06)$ & $-.06(.05)$ & $.05(.06)$ \\
\hline Complex Case & & & $-.04(.07)$ & $-.03(.09)$ & $-.07(.07)$ \\
\hline Court Politics & & & $-.15(.08)^{*}$ & & $-.13(.09)$ \\
\hline Observations & 287 & 286 & 184 & 286 & 183 \\
\hline Pseudo $\mathrm{R}^{2}$ & .01 & .05 & .01 & .07 & .04 \\
\hline
\end{tabular}

* Note: Dependent variable is case outcome coded $=1$ if the government prevails and coded $=0$ if the taxpayer prevails. All the independent variables are binary; the models present robust standard errors. Variables marked with *** indicates statistical significance at $\mathrm{p} \leq .01$ level and $* *$ at the $\mathrm{p} \leq .05$.

Together Tables 4, 5, and 6 offer a preliminary explanation for the increased number of pro-government decisions in times of war. As discussed above, if the justices believe they lack the expertise to make informed choices about wartime strategy, and perhaps even fear that they could undermine national success through unintentional interferences, they are likely to defer to Congress and the President in times of war. The empirical data suggest the justices do seek to accommodate the elected branches of government but not in every case that shows up on the docket, only in cases that address issues that Congress and the President have expressly addressed. For this reason, the findings suggest the Court seeks to support national security through limited deference to the majoritarian bodies.

There is one final mechanism - the rally effect — that must also be investigated before we reach a conclusion as to the mechanism that best explains judicial decisionmaking times of war. As noted above, many surveys find that when the nation is under siege from a perceived international threat, citizen rally around the flag and offer increased support for the President. The rally effect tends to lead to a generalized support for executive decision-making and enables the adoption of policies that may not be possible in peacetime. If the justices, like Americans generally, experience these nationalistic feelings then they may be more sympathetic to the government's legal positions in the tax cases on the docket irrespective of the issues involved.

Survey data indicates that Americans rallied around the flag in 1941, 1950, 1967, and 1969, years in which the Court decided a total of 55 tax cases. The question I seek to answer is whether the likelihood of a pro-government decision is greater during these rally periods than during the non-rally periods. Thus for purpose of this part of the study, rallies are the treatment variable of interest. Table 7 presents a model that tests for a 
correlation between rally effects and judicial decision-making and finds a negative effect. This means that the justices are less likely to exhibit a pro-government bias during periods when the nation-at-large is feeling strong nationalistic feelings due to perceived foreign threats. Because most of the cases were decided during the WWII rally $(n=30)$, I examined this rally separately and found an even stronger negative effect. Adding the same control variables from above does not change this result. It is important to note, however, that the rally findings are no statistically significant; in fact, the confidence intervals indicate that rallies may not affect the justices at all or the effect may be quite a bit more negative than indicated in Table 7 . None of the findings suggest that we should expect a positive coefficient on the rally variable and thus the best estimate we have is that the rallies have either no affect or a negative effect.

Table 7: Rally Effects on Statutory Cases

\begin{tabular}{lcccc}
\hline \hline \multicolumn{5}{c}{ Probit Models With Marginal Effects } \\
\hline \hline Independent Variable & $(1)$ & $(2)$ & \multicolumn{1}{c}{$(3)$} & $(4)$ \\
\hline \hline Rally & -.09 & & $-01(.07)$ & \\
& $(.07)$ & & & $-.16(.10)$ \\
World War II Rally & & $-.14(.10)$ & $.04(.66)$ & $.01(.07)$ \\
Economic Crisis & & & $.01(.04)$ & $.02(.04)$ \\
Textualist Method & & & $-.008(.04)$ & $-.04(.04)$ \\
Substantive method & & & $.11(.08)$ & $.10(.06)$ \\
Complex Case & & & 421 & 421 \\
\hline Observations & 421 & 421 & .004 & .01 \\
\hline Pseudo R ${ }^{2}$ & .003 & .004 & & \\
\hline \hline
\end{tabular}

* Note: Dependent variable is case outcome coded $=1$ if the government prevails and coded $=0$ if the taxpayer prevails. All the independent variables are binary; the models present robust standard errors. Variables marked with *** indicates statistical significance at $\mathrm{p} \leq .01$ level and $* *$ at the $\mathrm{p} \leq .05$.

The fact that Table 7 rules out the possibility that rallies increase the probability that the Court will issues a pro-government decision indicates that the conclusions from above are very robust. That is to say, the raw data along with the thirteen statistical models depicted above suggest that the Court is willing to defer to the elected branches of government during times of war. This deference, however, is not grounded on irrational exuberance associated with the rally effect nor is it unbounded in the sense that the Court will defer on all issues that emerge on the docket. Rather the deference is restrained and limited as evidenced by the fact that it only emerges in cases that raise similar issues to those directly addressed by Congress and the President. For this reason, we observe an increase in the number of pro-government decisions in WWI in corporate cases (but not individual cases); in WWII in individual cases (but not corporate cases) and no affects in the later wars when the politicians sent conflicting signals on the importance of difference taxpayers' roles in funding the national emergency. 


\section{CONCLUSION}

This paper seeks to identify and explain the effects of major wars on U.S. Supreme Court decision-making in the context of taxation. At first cut, it may not seem obvious why we should expect to observe a correlation between military activities and judicial fiscal policy. After all, the justices have no authority whatsoever to engage in military planning or to adopt laws that relieve the budgetary pressures that tend to emerge in times crisis. The Court, however, is able to contribute to the revenue-raising efforts indirectly by adopting a pro-government attitude in wartime periods. As the probability of a government win increases, for example, the expected revenue to the federal fisc also increases.

Various scholars have investigated this question in the context of constitutional rights and liberties have reached mixed and often conflicting results. One explanation for the assorted findings in the extant literature is related to the fact that judicial incentive are themselves contradictory in the rights and liberties context and thus it is not only impossible to predict ex ante how wars will affect the justices, but the results themselves are likely to be sensitive to the specific cases analyzed. In the fiscal context, by contrast, there are various judicial incentives at work but all operate in the same direction - and all in favor the government. For this reason, I am able to identify whether war induces the Court to change its behavior as well as why the observed changes occur.

Relying on Supreme Court tax decisions issued between the years 1909-2000, this paper identifies a strong positive correlation between major wartime activity and the probability that the government will prevail. This pro-government bias appears to operate through the judicial belief that Congress and the President are better suited to address national emergencies. This perceived imbalance of expertise, however, does not lead the Court to adopt a strategy of total deference, but rather a restricted form that involves accommodation only on issues that Congress and the President have signaled are important to the on-going war activities. These findings are robust and rule out the possibility that the Court is motivated by short-term irrational exuberance for federal policymakers associated with the so-called "rally-effect" that emerges when Americans feel threatened by forces abroad. 


\section{DATA CODING APPENDIX}

Data Collection and Coding Procedures

1. The 1,113 tax cases were obtained through the Westlaw search identified in the text at footnote 30 .

2. War is a binary variable $=1$ if the military activities involved nuclear capabilities or the mobilization of multiple aircraft carrier task groups, battalions, or combat wings and $=0$ otherwise. ${ }^{96}$

The start date of a major war was identified by the earliest of the following: the declaration of war, the deployment of troops, or a Presidential request for escalated war powers. The end date of the war was as the date upon which the U.S. President officially declared the war to be over, through a treaty, public statement, or so forth. Specifically,
a. WWI: $4 / 6 / 1917$ through $6 / 28 / 1919$
b. WWII: $12 / 7 / 1941$ through $8 / 14 / 1945$
c. Korean War: 6/27/1950 through $7 / 27 / 1953$
d. Vietnam War: 2/7/1965 through 1/27/1973
e. Gulf War: 1/16/1991 through 4/11/1991

3. Economic Crisis is a binary variable $=1$ if a major economic crisis existed and $=0$ otherwise. A major economic crisis is defined as a decline in the country's GDP for 4 or more successive quarters and at least once by five or more percentage points in that period. There is no widely accepted definitions of a major economic crisis; a recession is defined a period when the GDP decreases in two or more successive quarters. My definition picks up the years from 1929-1932 and 1945-1946.

4. Corporate Taxpayer is a binary variable $=1$ if the party litigating the case is a corporate entity and 0 otherwise. A corporate entity is a business firm whose articles of incorporation have been approved by some state; this excludes SCorporations and various other pass-through entities

5. Individual Taxpayer is a binary variable $=1$ the party litigating the case is an individual and $=0$. Individuals do not include S-Corps, Pass-through entities, or estates.

\footnotetext{
${ }^{96}$ This is the commonly-used definition the law and political science literatures. See, e.g., William Howell \& Jon C. Pevehouse, President, Congress, and the Use of Force, 59 InTERNAT'L ORG. 209, 217 (2005).
} 
6. Textualist Method is a binary variable $=1$ if the Court adopted a method of statutory interpretation that relied implicitly or explicitly on the text of the statute or on textual cannons of interpretation and $=0$.

7. Substantive Method is a binary variable $=1$ if the Court looked to substantive rationales for interpreting the statute that were unrelated to text of congressional intent and $=0$. Substantive rationales include general concerns for the economy, fairness, revenue-raising, and so-forth

8. Complex Case is a binary variable $=1$ if the Court addressed more than one issue and $=0$.

9. Court Ideology is a continuous variable equal to the "Martin-Quinn" score. There are a variety of measures that one might use, but for purposes of this study I rely on the "Martin-Quinn" scores because they are available for the most Supreme Court Terms (from 1937-2005 — no judicial ideology scores are yet available going back to 1909 , the start date of this study). The MartinQuinn scores are grounded in a special model of voting which assumes the Justices have choices over alternatives. A negative score indicates a relatively liberal viewpoint, a score equal to 0 indicates moderate views, and a positive score indicates a relatively conservative viewpoint. ${ }^{97}$ Theoretically, the score are unbounded, but empirically the most liberal score in the database is $\mathbf{X X}$ and the most conservative score is $\mathbf{X X}$. I relied on the scores of the median justice for each term, which ranges from -.9317 and .6243, which are very moderate and typical of what we would expect of a median justice.

Interpretation of Probit Model Coefficients obtained through STATA code "dprobit."

\footnotetext{
${ }^{97}$ See Andrew Martin \& Kevin Quinn, Dynamic Ideal Point Estimation via Markov Chain Monte Carlo for the U.S Supreme Court, 1953-1999, 10 PoL. ANALYSIS 134 (2002); see also Jeffrey A. Segal \& Albert D. Cover, Ideological Values and the Votes of U.S. Supreme Court Justices, 83 Am. POL. SCI. REV. 557 (1989) (providing an alternative measure of identifying judicial ideology).
} 